\title{
PERAN GURU PENDIDIKAN AGAMA ISLAM DALAM MENINGKATKAN MOTIVASI BERAGAMA SISWA SMP ISLAM AL-AZHAR 5 CIREBON
}

\author{
Asep kurniawan \\ asepqurniawan.ak@gmail.com
}

\begin{abstract}
Abstrak
Peranan guru sangatlah besar pengaruhnya dalam perkembangan jiwa keagamaan siswa, termasuk di dalamnya bagaimana guru memberikan perhatian kepada anak didik dalam mendidik, mengajar dan mengevaluasi baik dalam menyampaikan materi di kelas ataupun dalam menjalankan aktivitas sehari-hari siswa di sekolah. Apabila guru kurang memberikan perhatian kepada siswa dan salah dalam mendidik dan mengajar anak maka anak pun akan mudah terbawakepada hal-hal yang tidak baik. Pendidikan Agama Islam membentuk aspek jasmani dan rohani seseorang berdasarkan kepada nilai-nilai ajaran agama Islam yang terkandung dalam kitab suci al-Qur'an dan sunah Rasulullah. Kedua aspek tersebut diharapkan tumbuh seimbang, sehingga tidak menimbulkan kesenjangan antara kebutuhan rohaniah dan kebutuhan jasmaniah. Tujuan penelitian ini adalah untuk mengetahui seberapa besar peran guru PAI dalam meningkatkan motivasi beragama siswa. Penelitian ini memakai metode deskriptif analisis dengan menggunakan instrument kuesioner (angket) dan wawancara sebagai sumber datanya. Dari penelitian yang telah dilakukan kepada sejumlah siswa yang menjadi sampel, maka dilakukan analisa data yang merupakan bagian penting dalam metode ilmiah untuk menjawab masalah penelitian ini. Dalam menganalisa data, maka dapat diambil kesimpulan bahwa peranan guru PAI dalam bentuk perhatiannya sangat besar sekali sehingga berimplikasi pada sikap keberagamaan siswa yang terlihat baik sekali. Selain itu, sekolah juga memainkan peranannya sebagai lembaga pendidikan dengan memberikan pengajaran dan kegiatan-kegiatan yang dapat menumbuhkembangkan sikap keagamaan siswa.
\end{abstract}

Kata Kunci: Guru, Motivasi, Perilaku, Beragama

\section{Kata Kunci: Pendidikan, Pendidikan Islam dan Pengajaran}

\section{A. Latar Belakang Masalah}

Setiap manusia pasti mengalami dan melaksanakan pendidikan. Karena pendidikan tidak dapat dipisahkan dari kehidupan manusia. Anak-anak menerima pendidikan dari orang tuanya dan ketika anak-anak ini sudah dewasa dan berkeluarga mereka juga akan mendidik anak-anaknya. Begitu pula di sekolah dan perguruan tinggi, para siswa dididik oleh guru dan dosen. Jadi pendidikan tidak dilakukan hanya di sekolah. Tetapi dimanapun dan kapanpun pendidikan dapat dilaksanakan. Pendidikan bagi kehidupan manusia merupakan kebutuhan mutlak yang harus dipenuhi sepanjang hayat. Tanpa pendidikan sama sekali mustahil suatu kelompok manusia dapat hidup berkembang sejalan dengan aspirasi (cita- 
cita) untuk maju, sejahtera dan bahagia menurut konsep pandangan hidup mereka.

Manusia membutuhkan pendidikan dalam kehidupannya. Pendidikan merupakan usaha agar manusia dapat mengembangkan potensi dirinya melalui proses pembelajaran dan/ cara lain yang dikenal dan diakui oleh masyarakat. Pendidikan juga merupakan proses pemupukan pengetahuan, keterampilan dan sikap untuk mewujudkan segenap potensi yang ada dalam diri seseorang. Karena tujuan utama dan yang paling penting dari pendidikan adalah membuat murid menemukan dirinya sendiri (dimensi batin) memahami kapasitasnya dan mendisiplinkan dirinya sendiri.

Oleh karena itu, Undang-Undang Dasar Negara Republik Indosesia Tahun 1945 pasal 31 ayat (1) menegaskan bahwa setiap warga negara berhak mendapat pendidikan, dan ayat (3) menyebutkan bahwa pemerintah mengusahakan dan menyelenggarakan suatu sistem pendidikan nasional yang meningkatkan keimanan dan ketakwaan serta akhlak mulia dalam rangka mencerdaskan kehidupan bangsa yang diatur dengan undang-undang. Kata keimanan dan ketakwaan menegaskan bahwa agama memiliki kedudukan yang penting dalam pendidikan nasional.Untuk itu, seluruh komponen bangsa wajib mencerdaskan kehidupan bangsa yang sekaligus membangun keimanan dan ketakwaan secara terintegrasi atau seutuhnya.Dengan kata lain, manusia seutuhnya meliputi keseluruhan dimensi kehidupan manusia: fisik, psikis, mental/moral, spiritual dan religius.

Kalau diamati secara seksama, tujuan pendidikan baik pendidikan Nasional maupun pendidikan Islam mempunyai arah yang sama. Adapun tujuan pendidikan Nasional atau pendidikan di Indonesia sebagaimana tercantum dalam Garis-Garis Besar Haluan Negara (GBHN) tahun 1999 adalah sebagai berikut:

"Mengembangkan kualitas sumber daya manusia sedini mungkin secara terarah, terpadu dan menyeluruh melalui berbagai upaya proaktif dan reaktif oleh seluruh komponen bangsa agar generasi muda dapat berkembang secara optimal di sertai dengan hak dukungan sesuai dengan potensinya.” (MPR RI, 1999:33)

Sedangkan tujuan pendidikan Islam tidak begitu berbeda dengan tujuan pendidikan pada umumnya, hanya didasari dengan prinsip-prinsip kehidupan beragama sesuai dengan tujuan hidup muslim. Tujuan ini mengarah kepada tujuan akhirdan tertinggi yang akan dicapai pendidikan Islam, tujuan terakhirnya merupakan kristalisasi nilai-nilai idealitas Islam yang diwujudkan dalam pribadi anak didik. Maka tujuan akhir itu harus 
meliputi semua aspek pola kepribadian yang ideal. Tujuan yang dimaksud adalah untuk mendapatkan ridha dan beribadah kepada Allah swt serta mencapai kebahagiaan hidup di dunia dan di akhirat kelak. Tujuan hidup manusia itu menurut Allah ialah beribadah kepada Allah, ini sesuai dengan Q.S. ad-Dzariyat: 56:

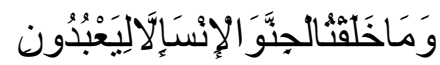

"Dan Aku tidak menciptakan jin dan manusia melainkan supaya mereka mengabdi kepada-Ku."

Menjadi 'abid merupakan perwujudan dari kepribadian muslim, sehingga apabila manusia telah bersikap menghambakan diri sepenuhnya kepada Allah berarti ia telah berada di dalam dimensi kehidupan yang mensejahterakan hidup di dunia dan membahagiakan di akhirat, inilah tujuan pendidikan Islam yang tertinggi. Beribadah kepada Allah yang merupakan repleksi menanamkan taqwa dan akhlak serta menegakkan kebenaran dalam rangka membentuk manusia yang berpribadi dan berbudi luhur menurut ajaran Islam (Arifin, 1994:41). Karena tujuan utama dan pertama dalam pendidikan agama adalah penumbuhan dan pengembangan sikap positif dan cinta kepada agama, itulah yang nantinya akan membuat anak menjadi orang dewasa yang hidup mengindahkan ajaran agama, dimana akhlak atau moralnya, tingkah laku, tutur kata dan sopan santun menggambarkan ajaran agama dalam pribadinya. Sikap itulah yang nantinya akan menjauhkan dirinya dari berbagai godaan duniawi yang bertentangan dengan ajaran agama (Ramayulis, 2001:101).

Unsur dominan dalam tujuan pendidikan Islam adalah pembentukan sikap, akhlak terpuji dan budi pekerti yang luhur yang mampu dan sanggup menghasilkan manusia-manusia yang berkarakter, bermoral baik, keras kemauan, sopan dalam berbicara, dan berbuat mulia dalam tingkah laku, jujur dan menghindari suatu perbuatan yang tercela dan mengingat Allah dalam setiap aktivitas yang dilakukan. Dengan demikian dapat membentuk kepribadian siswa yang Islami.

Akan tetapi, sejauh ini pelaksanaan pendidikan agama yang berlangsung di sekolah umum masih mengalami banyak kelemahan. Kelemahan ini disebabkan karena praktek pendidikan hanya memperhatikan aspek kognitif semata dari pertumbuhan kesadaran nilai-nilai agama, dan mengabaikan pembinaan aspek afektif dan konatif-voletif, yakni kemauan dan tekad untuk mengamalkan nilai-nilai ajaran agama, seperti shalat 
berjamaah. Akibat terjadi kesenjangan antara pengetahuan dan pengamalan, antara gnosis dan praxis dalam kehidupan nilai agama atau dalam praktek pendidikan agama berubah menjadi pengajaran agama, sehingga tidak membentuk pribadi-pribadi bermoral, padahal intisari dari pendidikan agama adalah pendidikan moral (Muhaimin, 2010:23).

Dalam pelaksanaan pendidikan agama diberbagai sekolah umum, belum seperti yang diharapkan, karena berbagai kendala dalam bidang kemampuan pelaksanaan metode, sarana fisik dan non fisik. Disamping suasana lingkungan pendidikan yang kurang menunjang suksesnya pendidikan mental spiritual dan moral. Padahal fasilitas dasarnya telah disediakan oleh pemerintah melalui Tap-Tap MPR, pengaturan perundangan lainya, serta berbagai proyek pembangunan sektor agama dan pendidikan.

Adanya pelajaran agama di sekolah di satu pihak sebagai upaya pemenuhan hakekat manusia sebagai makhluk religius (homo religiousus). Sekaligus di lain pihak pemenuhan apa yang objektif dari para siswa akan kebutuhan pelayanan hidup keagamaan. Agama dan hidup beriman merupakan suatu yang objektif menjadi kebutuhan setiap manusia.
Diketahui bahwa agama (Islam) dan pendidikan adalah dua hal yang satu sama lain saling berhubungan. Melalui agama, manusia diarahkan menjadi manusia seutuhnya sesuai dengan nilainilai ajaran Islam. Proses pengembangannya adalah melalui pendidikan. Karena dengan pendidikan orang akan menjadi lebih dewasa dan lebih mampu baik dari segi kecerdasannya maupun sikap mentalnya.

Pendidikan menjadi kunci utama dalam pembentukan sikapkeberagamaan anak. Pertambahan usia anak memiliki konsekuensi padaperubahan proses pendidikan yang mereka terima. Oleh sebab itu, denganbertambahnya usia anak dan berubahnya perilaku mereka maka harus disertai pendidikan yang tepat sehingga memiliki sikap dan tingkah laku serta budi yang luhur.

Dengan sikap keberagamaan yang mereka miliki, maka akan dapat mengontrol dan mendorong seseorang untuk bertingkah laku sesuai dengan norma agama. Karena pendidikan agama yang bersifat dresser dan menggugah akal serta perasaan memegang peranan penting dalam pembentukan sikap keagamaan (Ramayulis, 2002:96).

Dalam proses pendidikan, pendidik memiliki peran kunci dalam menentukan kualitas pembelajaran. Yakni menunjukkan cara mendapatkan 
pengetahuan (cognitive), sikap dan nilai (affective), dan keterampilan (psychomotor). Dengan kata lain tugas dan peran pendidik yang utama terletak pada aspek pembelajaran. Pembelajaran merupakan alat untuk mencapai tujuan pendidikan. Singkatnya, dapat dikatakan bahwa kualitas pendidikan sangat dipengaruhi oleh kualitas pendidiknya (Fatah Yasin, 2008:67). Dan seorang guru dalam kehidupan sehari-harinya selalu dijadikan sebagai figur manusia yang selalu dapat digugu dan ditiru oleh anak didiknya.

Pelaksanaan pendidikan agama Islam tidak hanya disampaikan secara formal dalam suatu proses pembelajaran, namun dapat pula dilakukan di luar proses pembelajaran dalam kehidupan sehari-hari. Guru bisa memberikan pendidikan agama ketika menghadapi sikap atau perilaku peserta didik. Dari hasil pendidikan agama dapat membentuk pengetahuan, sikap, perilaku, dan pengalaman keagamaan yang baik dan benar. Peserta didik akan mempunyai akhlak mulia, perilaku jujur, disiplin, dan semangat keagamaan sehingga menjadi dasar untuk meningkatkan kualitas dirinya.

Idealnya memang seperti itu, namun kenyataan di lapangan, masih banyak guru yang belum menjalankan perannya sebagai figur yang patut diteladani dalam pembinaan keagamaan. Kita sering mendengar ada oknum guru yang berbuat asusila dengan siswanya sendiri (Rakyat Cirebon, 2016), penyalahgunakan psikotropika (Justang Muhammad, 2017) dan lainlain.Walaupun contoh tersebut bersifat kasuistis, namun cukup membuat miris dunia pendidikan, terutama pendidikan agama, karena siswa membutuhkan peran guru sebagai figur yang bisa diteladani.

Dengan demikian dapat dikatakan bahwa peranan guru adalahterciptanya serangkaian tingkah laku yang saling berkaitan yang dilakukandalam suatu situasi tertentu serta berhubungan dengan kemajuan perubahan tingkah laku dan perkembangan siswa yang menjadi tujuannya (Uzer Usman, 2009:4). Peran guru dan pengaruhnya terhadap perilaku siswa sudah banyak dibuktikan dalam berbagai riset, seperti Jere Brophy (1986). Demikian pula hasil temuanpenelitian Yousef Mehdipour1dan Balaramulu (2013:65) menyebutkan:

Students (50\%) indicated that important qualities of teacher's Behavior were punctuality, honesty, hardworking, friendly, confident and competency. $69 \%$ of the students opined that they participated actively in the classes because they had a sincere relationship with their teachers and also $67 \%$ of students didn't 
like teachers think badly of them if they didn't it. Majority of the students informed that they understand some of lessons better because their teacher explained the lesson very well (88\%) and use different teaching techniques in class(74\%). hence, teacher's friendly behavior and teacher's attitude toward the students had impact on activities and selfregulation behavior in students.

(50\% siswa menunjukkan bahwa perilaku guru yang baik adalah ketepatan waktu, kejujuran, pekerja keras, ramah, percaya diri dan kompeten. $69 \%$ siswa berpendapat bahwa mereka berpartisipasi aktif di kelas karena mereka memiliki hubungan yang tulus dengan guru mereka dan juga $67 \%$ siswa tidak menyukai guru yang berpikir buruk tentang mereka jika mereka tidak melakukannya. Mayoritas siswa memberi tahu bahwa mereka memahami beberapa pelajaran lebih baik karena guru mereka menjelaskan pelajaran dengan sangat baik (88\%) dan menggunakan teknik pengajaran yang berbeda di kelas (74\%). Oleh karena itu, perilaku ramah guru dan sikap guru terhadap siswa berdampak pada aktivitas dan perilaku pengaturan diri pada siswa.

Pengaruh guru terhadap siswa yang besar seperti tersebut di atas, hendaknya dapat dipergunakan dalam menanamkan perilaku baik siswa dalam norma keagamaan. Untuk itu guru memainkan banyak perannya di lingkungan sekolah. Di dalam proses pembelajaran, seorang guru tidak hanya berperan sebagai seorang pendidik atau pengajar saja. Tetapi juga sebagai pemberi bimbingan dan penyuluhan.

Sebagai pengajar, guru bertugas membina perkembangan pengetahuan, sikap dan keterampilan. Guru mengetahui bahwa pada akhir setiap satuan pelajaran kadang-kadang hanya terjadi perubahan dan perkembangan pengetahuan saja. Mungkin pula guru telah bersenang hati bila telah terjadi perubahan dan perkembangan di bidang pengetahuan dan keterampilan, karena dapat diharapkannya efek tidak langsung, melalui proses transfer bagi perkembangan di bidang sikap dan minat murid.

Dengan kata lain, bahwa kemungkinan besar selama proses belajar mengajar hanya tercapai perkembangan di bagian minat. Sedang efek dan transfernya kepada keseluruhan perkembangan sikap dan kepribadian berlangsung di luar situasi belajarmengajar itu sendiri. Hal demikian itu tampaknya bersifat umum, walaupun sesungguhnya kurang memenuhi harapan dari pengajaran agama. Dari kenyataan itu pulalah terbukti bahwa peranan guru sebagai pendidik dan pembimbing masih berlangsung terus walaupun tugasnya sebagai pengajar telah selesai. 
Sebagai pembimbing, guru lebih suka kalau mendapatkan kesempatan menghadapi sekumpulan murid-murid di dalam interaksi belajar-mengajar. Ia memberi dorongan dan menyalurkan semangat menggiring mereka, sehingga mereka dapat melepaskan diri dari ketergantungannya kepada orang lain dengan tenaganya sendiri.

Pemberian bimbingan bagi guru agama meliputi bimbingan belajar dan bimbingan perkembangan sikap keagamaan. Dengan demikian membimbing dimaksudkan agar setiap murid diinsyafkan mengenai kemampuan dan potensi diri murid yang sebenarnya dalam kapasitas belajar dan bersikap. Jangan sampai murid-murid menganggap rendah atau meremehkan kemampuannya sendiri dalam potensinya untuk belajar dan bersikap sesuai dengan ajaran agama Islam (Zakiah Daradjat, 2008:265-267).

Selain itu juga, guru berperan sebagai pengarah belajar (director of learning). Dalam hal ini guru berperan untuk senantiasa menimbulkan, memelihara, meningkatkan motivasi siswa untuk belajar. Dalam hubungan ini, guru mempunyai peran sebagai motivator keseluruhan kegiatan belajar siswa. Sebagai motivator belajar guru harus mampu untuk: (1) membangkitkan dorongan siswa untuk belajar, (2) menjelaskan secara konkret kepada siswa apa yang dapat dilakukan pada akhir pengajaran, (3) memberikan reward (hadiah) untuk prestasi yang dicapai siswa, dan (4) membuat regulasi (aturan) perilaku siswa.15 Dalam hal ini, pendekatan yang digunakan guru dalam proses pembelajaran adalah pendekatan pribadi. Melalui pendekatan pribadi ini, diharapkan guru dapat mengenal dan memahami siswa secara lebih mendalam sehingga dapat membantu dalam keseluruhan proses belajarnya.

Dari uraian diatas, dapat disimpulkan bahwa guru pendidikan agama Islam di sekolah mempunyai peranan yang sangat penting dalam proses Pendidikan Agama Islam untuk menanamkan sikap keberagamaan pada diri siswa. Masalah ini sangat penting untuk diteliti karena berkaitan dengan Pendidikan Agama Islam yang diberikan guru di sekolah agar para siswa mempunyai sikap keberagamaan dalam seluruh aspek kehidupannya. Oleh sebab itu, penelitian ini penulis beri judul: "Peran Guru Pendidikan Agama Islam dalam Meningkatkan Motivasi Beragama Siswa di SMP Islam al-Azhar 5 Cirebon."

\section{B. Tinjauan Teori}

Peran guru Pendidikan Agama Islam dapat diartikan sebagai tugas 
seorang guru Pendidikan Agama Islam dalam proses belajar mengajar yang meliputi 3 langkah yaitu: mendidik, mengajar dan mengevaluasi. Mulyasa mengatakan bahwa diantara tugas guru yang utama dalam pembelajaran adalah:

1. Sebagai Pendidik

Mendidik dapat diartikan
sebagai suatu usaha untuk
mengantarkan anak didik ke arah
kedewasaannya baik secara jasmani
maupun rohani. Oleh karena itu,
mendidik dikatakan sebagai upaya
pembinaan pribadi, sikap mental dan
akhlak anak didik. Dibandingkan
dengan pengertian "mengajar", maka
pengertian "mendidik"
mendasar. Mendidik tidak sekedar
transfer of knowledge, tetapi juga
transfer of values. Mendidik diartikan
lebih komprehensif, yakni usaha
membina diri anak didik secara utuh,
baik matra kognitif, psikomotorik
maupun afektif, agar tumbuh sebagai
manusia-manusia yang berpribadi
(Mulyasa, 2006:37).
(Mulyasa, 2006:37).

Guru adalah pendidik, yang menjadi tokoh, panutan, dan identifikasi bagi para peserta didik, dan lingkungannya. Oleh karena itu, guru harus memiliki standar kualitas pribadi tertentu, yang mencakup tanggung jawab, wibawa, mandiri dan disiplin.

Berkaitan dengan tanggung jawab; guru harus mengetahui, serta memahami nilai, norma moral, dan sosial, serta berusaha berperilaku dan berbuat sesuai dengan nilai dan norma tersebut. Guru juga harus bertanggung jawab terhadap segala tindakannya dalam pembelajaran di sekolah, dan dalam kehidupan bermasyarakat.

Jadi, dapat disimpulkan bahwa peran guru Pendidikan Agama Islam sebagai pendidik sangatlah berat sekali. Karena dalam mendidik seorang guru PAI secara tidak langsung dituntut untuk memelihara dan membimbing anak didik untuk berakhlak mulia dan mempunyai kecerdasan pikiran yang dewasa. Dengan kata lain, seorang guru mempunyai tugas untuk membina diri anak didik secara utuh.

2. Sebagai Pengajar

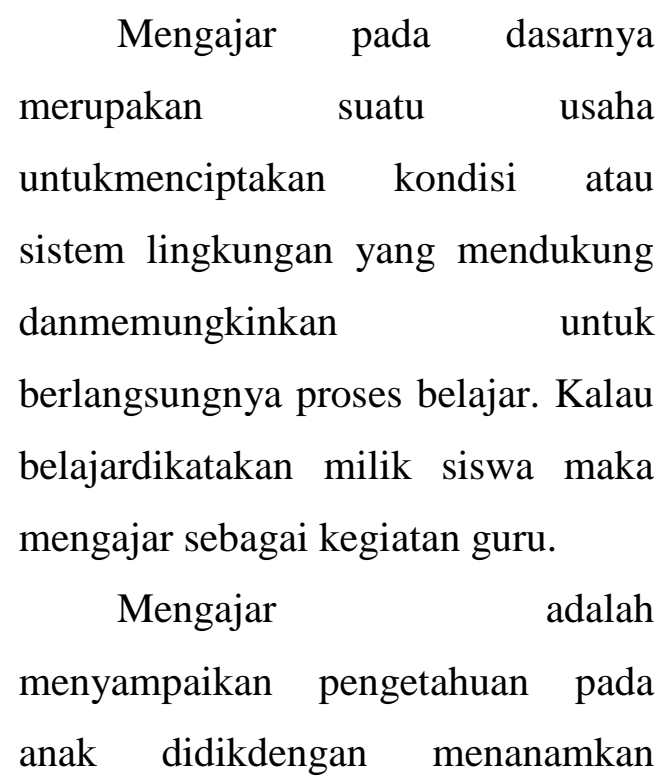


pengetahuan kepada anak didik dengan suatuharapan terjadi proses pemahaman yang terjadi melalui prosesbelajar (Sardiman, 2000:4748).

Kegiatan belajar peserta didik dipengaruhi oleh berbagai faktor, seperti motivasi, kematangan, hubungan peserta didik dengan guru, kemampuan verbal, tingkat kebebasan, rasa aman, dan keterampilan guru dalam berkomunikasi. Jika faktor-faktor diatas dipenuhi, maka melalui pembelajaran peserta didik dapat belajar dengan baik. Sehubungan dengan itu, sebagai orang yang bertugas menjelaskan sesuatu, guru harus berusaha membuat sesuatu menjadi jelas bagi peserta didik, dan berusaha lebih terampil dalam memecahkan masalah. Untuk itu, terdapat beberapa hal yang perlu dilakukan guru dalam pembelajaran, sebagai berikut:

a. Membuat ilustrasi: pada dasarnya ilustrasi menghubungkan sesuatu yang sedang dipelajari peserta didik dengan sesuatu yang telah diketahuinya, dan pada waktu yang sama memberikan tambahan pengalaman kepada mereka.

b. Mendefinisikan: meletakkan sesuatu yang dipelajari secara jelas dan sederhana, dengan menggunakan latihan dan pengalaman serta pengertian yang dimiliki oleh peserta didik.

c. Menganalisis: membahas masalah yang telah dipelajari bagian demi bagian, sebagaimana orang mengatakan: "cuts the learning into chewable bites".

d. Mensintesis: mengembalikan bagian-bagian yang telah dibahas ke dalam suatu konsep yang utuh sehingga memiliki arti, hubungan antara bagian yang satu dengan yang lain Nampak jelas, dan setiap masalah itu tetap berhubungan dengan keseluruhan yang lebih besar.

e. Bertanya: mengajukan pertanyaanpertanyaan yang berarti dan tajam agar apa yang dipelajari menjadi lebih jelas, seperti yang dilakukan Socrates.

f. Merespon: mereaksi atau menanggapi pertanyaan peserta didik.Pembelajaran akan lebih efektif jika guru dapat merespon setiappertanyaan peserta didik.

g. Mendengarkan: memahami peserta didik, dan berusaha menyederhanakan setiap masalah, serta membuat kesulitan Nampak jelas bagi guru maupun peserta didik. 
h. Menciptakan kepercayaan: pesetra didik akan memberikan kepercayaan terhadap keberhasilan guru dalam pembelajaran dan pembentukan kompetensi dasar.

i. Memberikan pandangan yang bervariasi: melihat bahan yan dipelajari dari berbagai sudut pandang, dan melihat masalah dalam kombinasi yang bervariasi.

j. Menyediakan media untuk mengkaji materi standar: memberikan pengalamn yang bervariasi melalui media pembelajaran dan sumber belajar yang berhubungan dengan materi standar.

k. Menyesuaikan metode pembelajaran: menyesuaian metode pembelajaran dengan kemampuan dan tingkat perkembangan peserta didik serta menghubungkan materi baru dengan sesuatu yang telah dipelajari.

1. Memberikan nada perasaan: membuat pembelajaran menjadi lebih bermakna, dan hidup melalui antusias dan semangat.

Agar pembelajaran memiliki kekuatan yang maksimal, guruguru harus senantiasa berusaha untuk mempertahankan dan meningkatkan semangat yang telah dimilikinya ketika mempelajari materi standar.

Sebagai pengajar, guru harus memiliki tujuan yang jelas, membuat keputusan secara rasional agar peserta didik memahami keterampilan yang dituntut oleh pembelajaran. Untuk kepentingan tersebut, perlu dibina hubungan yang positif antara guru dengan peserta didik. Hubungan ini menyangkut bagaimana guru merasakan apa yang dirasakan peserta didiknya dalam pembelajaran, serta bagaimana peserta didik merasakan apa yang dirasakan gurunya. Sebaiknya guru mengetahui bagaimana peserta didik memandangnya, karena hal tersebut sangat penting dalam pembelajaran, baik di sekolah maupun di luar sekolah. Hal ini akan menjadi jelas jika secara hati-hatimenguji bagaimana guru merasakan apa yang dirasakan peserta didikdalam pembelajaran (empati)(Mulyasa, 2006:37-40).

Selain itu, Salah satu dari tahapan mengajar yang harus dilaluioleh seorang guru dalam proses pengajaran adalah "menyusunperencanaan pengajaran atau dengan kata lain disebut juga dengan"mendisain program pengajaran". 
R. D. Conners mengemukakan pula bahwa mengajar adalahsuatu perbuatan terpadu dan dilaksanakan secara bertahap, sepertidigambarkan melalui analisis mengajar berikut ini (Syafruddin Nurdin, 2002:84):

\begin{tabular}{|c|c|c|}
\hline \multicolumn{3}{|c|}{ Tugas Guru } \\
\hline $\begin{array}{c}\text { Tahap sebelum } \\
\text { pengajaran } \\
\text { (Pre- active) }\end{array}$ & $\begin{array}{l}\text { Tahap } \\
\text { pengajaran } \\
\text { (Inter- } \\
\text { active) }\end{array}$ & $\begin{array}{c}\text { Tahap } \\
\text { sesudah } \\
\text { pengajaran } \\
\text { (Post- } \\
\text { active) }\end{array}$ \\
\hline $\begin{array}{l}\text { Perencanaan } \\
\text { semester, catur } \\
\text { wulan unit, } \\
\text { satuan } \\
\text { pelajaran }\end{array}$ & $\begin{array}{l}\text { - Pengelola } \\
\text { an control } \\
\text { - Penyampa } \\
\text { ian } \\
\text { informasi } \\
\text { - Pengguna } \\
\text { an tingkah } \\
\text { laku } \\
\text { verbal dan } \\
\text { non verbal }\end{array}$ & $\begin{array}{l}\text { - Menilai } \\
\text { kemajua } \\
\text { n siswa } \\
\text { - Merenca } \\
\text { nakan } \\
\text { kegiatan } \\
\text { - Menilai } \\
\text { proses } \\
\text { belajar } \\
\text { mengajar }\end{array}$ \\
\hline $\begin{array}{l}\text { - Bekal } \\
\text { bawaan } \\
\text { siswa } \\
\text { - Perumusan } \\
\text { tujuan } \\
\text { - Pemilihan } \\
\text { metode, } \\
\text { pengalaman } \\
\text { belajar, } \\
\text { bahan dan } \\
\text { peralatan }\end{array}$ & $\begin{array}{l}\text { - Balikan } \\
\text { - Penerapan } \\
\text { prinsip } \\
\text { psikologi }\end{array}$ & \\
\hline $\begin{array}{l}\text { Mempertimban } \\
\text { gkan ciri-ciri } \\
\text { siswa, langkah } \\
\text { pengajaran, } \\
\text { pola } \\
\text { pengelompoka } \\
\text { n dan prinsip } \\
\text { belajar. }\end{array}$ & 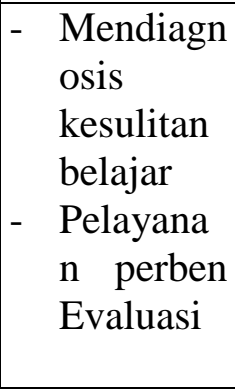 & $\begin{array}{l}\text { Hasil } \\
\text { belajar } \\
\text { siswa: } \\
\text { kognitif, } \\
\text { dan } \\
\text { psikomoto } \\
\text { rik. }\end{array}$ \\
\hline
\end{tabular}

Agar bahan pelajaran dapat disajikan kepada siswa dalam jam pelajaran tertentu guru harus membuat persiapan pelajaran yang dilakukan berdasarkan pedoman instruksional. Tiap pengajar harus membuat persiapan pelajaran sebelum ia dengan penuh tanggungjawab memasuki kelas. Mengajar adalah tugas yang begitu kompleks dan maha, sehingga tak dapat dilakukan dengan baik oleh siapa pun tanpa persiapan, sekalipun ia telah berpengalaman bertahuntahun.

Jadi, dapat disimpulkan bahwa peran guru Pendidikan Agama Islam sebagai pengajar adalah menyampaikan pengetahuan pada anak didik dalam proses belajar mengajar. Dalam hal ini diperlukan interaksi dan pemahaman psikologi yang mendalam dari seorang guru mengenai diri anak didik agar materi yang diberikan dapat dengan mudah dipahami oleh anak didik.

3. Sebagai Evaluator

Sebagai evaluator guru berperan untuk mengumpulkan data atau informasi tentang keberhasilan pembelajaran yang telah dilakukan (Wina Sanjaya, 2008:290).Selain itu juga, guru dituntut untuk menjadi seorang evaluator yang baik dan jujur, dengan memberikan penilaian yang menyentuh aspek ekstrinsik dan instrinsik. Penilaian terhadap aspek 
intrinsik lebih menyentuh kepada aspek kepribadian anak didik, yakni aspek nilai (values). Berdasarkan hal ini, guru harus bisa memberikan penilaian dalam dimensi yang luas. Penilaian terhadap kepribadian anak didik tentu lebih diutamakan daripada penilaian terhadap jawaban anak didik ketika diberikan tes (Djamarah, 2000:48).

Evaluasi atau penilaian merupakan aspek pembelajaran yang paling kompleks, karena melibatkan banyak latar belakang dan hubungan, serta variabel lain yang mempunyai arti apabila berhubungan dengan konteks yang hampir tidak mungkin dapat dipisahkan dengan setiap segi penilaian. Tidak ada pembelajaran tanpa penilaian, karena penilaian merupakan proses penetapan kualitas hasil belajar, atau proses untuk menentukan tingkat pencapaian tujuan pembelajaran oleh peserta didik.

Sebagai suatu proses, penilaian dilaksanakan dengan prinsipprinsip dan dengan teknik yang sesuai, mungkin tes atau non-tes. Teknik apapun yang dipilih, penilaian harus dilakukan denganprosedur yang jelas, yang meliputi tiga tahap, yaitu persiapan,pelaksanaan dan tindak lanjut.
Kemampuan yang harus dikuasai guru sebagai evaluator adalahmemahami teknik evaluasi, baik tes maupun non-tes yang meliputijenis masing-masing teknik, karakteristik, prosedur pengembangan,serta cara menentukan baik atau tidaknya ditinjau dari berbagai segi,validitas, reliabilitas, daya beda, dan tingkat kesukaran soal. 15

Adapun hasil pengajaran itu dikatakan betul-betul baik, apabilamemiliki ciri-ciri:

a. Hasil itu tahan lama dan dapat digunakan dalam kehidupan olehsiswa. Dalam hal ini guru akan senantiasa menjadi pembimbingdan pelatih yang baik bagi para siswa yang akan menghadapi ujian.Kalau hasil pengajaran itu tidak tahan lama dan lekas menghilang,maka hasil pengajaran itu berarti tidak efektif.

b. Hasil itu merupakan pengetahuan "asli" atau "otentik".Pengetahuan hasil proses belajar mengajar itu bagi siswa seolaholah telah merupakan bagian kepribadian bagi diri setiap siswa,sehingga akan dapat mempengaruhi pandangan dan caranyamendekati suatu permasalahan. Sebab pengetahuan itu dihayati danpenuh 
makna bagi dirinya (Sardiman, 2000:49-50).

Jadi, dapat disimpulkan bahwa peran guru Pendidikan AgamaIslam sebagai evaluator adalah menilai bagaimana hasil belajar siswadan pengaplikasian materi yang diajarkan dalam kehidupan sehari-haridengan menggunakan skala sikap yang meliputi aspek kognitif, afektifdan psikomotorik.

Ketiga rangkaian peran guru Pendidikan Agama Islam diatas adalah peran guru Pendidikan Agama Islam dalam proses belajar mengajar secara umum yang dilakukan di dalam kelas. Dan dapat diambil kesimpulan bahwa seorang guru Pendidikan Agama Islam dalam proses belajar mengajar dituntut untuk menyampaikan materi/pengetahuan kepada anak didik agar terjadi proses pemahaman dan pengamalan dalam kehidupan sehari-hari serta dapat menilai sejauh mana pemahaman anak didik akan materi yang telah diajarkan.

Sedangkan peran utama dari seorang guru Pendidikan Agama Islam yang tidak kalah pentingnya dari ketiga peran diatas adalah sebagai pembimbing. Peranan ini harus lebih dipentingkan, karena kehadiran guru di sekolah adalah untuk membimbing anak didik menjadi manusia dewasa susila yang cakap. Tanpa bimbingan, anak didik akan mengalami kesulitan dalam menghadapi perkembangan dirinya.

Sebagai pembimbing, guru lebih suka kalau mendapatkan kesempatan menghadapi sekumpulan murid-murid di dalam interaksi belajar-mengajar. Ia memberi dorongan dan menyalurkan semangat menggiring mereka, sehingga mereka dapat melepaskan diri dari ketergantungannya kepada orang lain dengan tenaganya sendiri.

Pemberian bimbingan bagi guru agama meliputi bimbingan belajar dan bimbingan perkembangan sikap keagamaan. Dengan demikian membimbing dan pemberian bimbingan dimaksudkan agar setiap murid diinsyafkan mengenai kemampuan dan potensi diri murid yang sebenarnya dalam kapasitas belajar dan bersikap. Jangan sampai murid-murid menganggap rendah atau meremehkan kemampuannya sendiri dalam potensinya untuk belajar dan bersikap sesuai dengan ajaran agama Islam (Zakiah Daradjat, 2008, 266-267).

\section{Metodologi Penelitian}


Penelitian menggunakan metode kualitatif diskriptif analitis dengan mengambil tempat di SMP Islam alAzhar 5 Cirebon pada bulan September sampai Desember 2016 pada kelas VIII. Populasi penelitian berjumlah 103 siswa dengan pengambilan sampel $48 \%$ dari populasi tersebut, yaitu 50 siswa. Penentuan sampel dilakukan secara acak (random sampling) dalam bentuk ordinal, dimana semua individu dalam populasi baik secara sendiri-sendoro atau bersama-sama diberi kesempatan yang sama untuk terpilih sebagai informan.

Teknik pengumpulan data dilakukan dengan teknik observasi mendalam terhadap sarana prasarana sekolah, struktur organisasi, keadaan guru dan siswa, serta kegiatan belajar mengajar di SMP Islam al-Azhar 5 Cirebon. Selanjutnya adalah teknik wawancara mendalam terhadap guru PAI, kepala sekolah, dan sejumlah siswa. Untuk mempertajam data digunakan pula teknik angket yang ditujukan kepada 50 siswa. Angket berbentuk tertutup dengan 5 alternatif jawaban. Teknik pengolahan data dilakukan melalui editing, coding, dan tabulating. Selanjutnya data-data dari hasil teknik di atas dianalisis dalam bentuk prosentase.

\section{Temuan Lapangan}

1. Peran Guru Pendidikan Agama Islam dalam Meningkatkan Motivasi Beragama Siswa SMP Islam al-Azhar 5 Cirebon

Tabel 4

Guru agama memerintahkan saya untuk melaksanakan shalat lima waktu

\begin{tabular}{|l|l|c|c|}
\hline No & $\begin{array}{c}\text { Alternatif } \\
\text { Jawaban }\end{array}$ & Frekuensi & $\begin{array}{c}\text { Prosentase } \\
\%\end{array}$ \\
\hline \multirow{1}{*}{1} & Sangat setuju & 42 & $84 \%$ \\
\cline { 2 - 4 } & Setuju & 7 & $14 \%$ \\
\cline { 2 - 4 } & Ragu-ragu & 1 & $2 \%$ \\
\cline { 2 - 4 } & Tidak setuju & - & - \\
\cline { 2 - 4 } & $\begin{array}{l}\text { Sangat tidak } \\
\text { setuju }\end{array}$ & - & - \\
\hline \multicolumn{2}{|l|}{ Jumlah } & 50 & $100 \%$ \\
\hline
\end{tabular}

Berdasarkan tabel di atas dapat dikemukakan bahwa hampir seluruh siswa (98\%) menyatakan menyukai perintah yang diberikan oleh guru agama untuk melaksanakan shalat lima waktu. Hanya sebagian kecil yang menyatakan ragu (2\%).

Tabel 5

Guru agama menasehati saya agar berpakaian rapi dan sopan

\begin{tabular}{|l|l|c|c|}
\hline No & $\begin{array}{l}\text { Alternat } \\
\text { if } \\
\text { Jawaban }\end{array}$ & $\begin{array}{c}\text { Frekuen } \\
\text { si }\end{array}$ & $\begin{array}{c}\text { Prosent } \\
\text { ase \% }\end{array}$ \\
\hline 2 & $\begin{array}{l}\text { Sangat } \\
\text { setuju }\end{array}$ & 39 & $78 \%$ \\
\cline { 2 - 4 } & Setuju & 9 & $18 \%$ \\
\hline \multirow{2}{*}{$\begin{array}{l}\text { Ragu- } \\
\text { ragu }\end{array}$} & 2 & $4 \%$ \\
\hline $\begin{array}{l}\text { Tidak } \\
\text { setuju }\end{array}$ & - & - \\
\hline $\begin{array}{l}\text { Sangat } \\
\text { tidak } \\
\text { setuju }\end{array}$ & - & - \\
\hline \multicolumn{2}{|c|}{ Jumlah } & 50 & $100 \%$ \\
\hline
\end{tabular}


Berdasarkan tabel di atas dapat dikemukakan bahwa hampir seluruh siswa (96\%) menyatakan menyukai nasehat guru agama untuk berpakaian rapi dan sopan. Hanya sebagian kecil yang menyatakan ragu (4\%).

\section{Tabel 6}

Guru agama menyarankan saya untuk mengikuti kegiatan ekstrakurikuler yang berkaitan dengan keagamaan di sekolah

\begin{tabular}{|l|l|c|c|}
\hline No & $\begin{array}{l}\text { Alternatif } \\
\text { Jawaban }\end{array}$ & $\begin{array}{c}\text { Freku } \\
\text { ensi }\end{array}$ & $\begin{array}{c}\text { Prose } \\
\text { ntase } \\
\%\end{array}$ \\
\hline 3 & $\begin{array}{l}\text { Sangat } \\
\text { setuju }\end{array}$ & 15 & $30 \%$ \\
\cline { 2 - 4 } & Setuju & 26 & $52 \%$ \\
\cline { 2 - 4 } & Ragu-ragu & 8 & $16 \%$ \\
\hline \multirow{2}{*}{$\begin{array}{l}\text { Tidak } \\
\text { setuju }\end{array}$} & 1 & $2 \%$ \\
\hline $\begin{array}{l}\text { Sangat } \\
\text { tidak setuju }\end{array}$ & - & - \\
\hline \multicolumn{2}{|c|}{ Jumlah } & 50 & $100 \%$ \\
\hline
\end{tabular}

Berdasarkan tabel di atas dapat dikemukakan bahwa sebagian besar siswa $(82 \%)$ menyatakan menyukai saran yang diberikan oleh guru agama untuk mengikuti kegiatan ekstrakurikuler yang berkaitan dengan keagamaan di sekolah. Hanya sebagian kecil yang menyatakan ragu (16 \%) dan sedikit sekali yang menyatakan tidak setuju (2\%).

Tabel 7

Guru agama mengajarkan saya untuk mengucapkan salam apabila bertemu dengan guru, dan teman di jalan

\begin{tabular}{|c|c|c|c|}
\hline No & $\begin{array}{c}\text { Alternatif } \\
\text { Jawaban }\end{array}$ & Frekuensi & $\begin{array}{c}\text { Prosent } \\
\text { ase \% }\end{array}$ \\
\hline
\end{tabular}

\begin{tabular}{|c|l|c|c|}
\hline 4 & $\begin{array}{l}\text { Sangat } \\
\text { setuju }\end{array}$ & 25 & $50 \%$ \\
\cline { 2 - 3 } & Setuju & 21 & $42 \%$ \\
\hline $\begin{array}{l}\text { Ragu- } \\
\text { ragu }\end{array}$ & 4 & $8 \%$ \\
\hline $\begin{array}{l}\text { Tidak } \\
\text { setuju }\end{array}$ & 1 & - \\
\hline $\begin{array}{l}\text { Sangat } \\
\text { tidak } \\
\text { setuju }\end{array}$ & - & - \\
\hline \multicolumn{2}{|c|}{ Jumlah } & 50 & $100 \%$ \\
\hline
\end{tabular}

Berdasarkan tabel di atas dapat dikemukakan bahwa hampir seluruh siswa (92\%) menyatakan setuju jika guru agama mengajarkan untuk mengucapkan salam apabila bertemu dengan guru, dan teman di jalan. Hanya sedikit sekali yang menyatakan ragu $(8 \%)$.

Tabel 8

Guru agama mengajarkan saya pelajaran mengenai macam-macam ibadah yang wajib dikerjakan

\begin{tabular}{|l|l|c|c|}
\hline No & $\begin{array}{c}\text { Alternatif } \\
\text { Jawaban }\end{array}$ & $\begin{array}{c}\text { Freku } \\
\text { ensi }\end{array}$ & $\begin{array}{c}\text { Prosentase } \\
\%\end{array}$ \\
\hline 5 & Sangat setuju & 30 & $60 \%$ \\
\cline { 2 - 4 } & Setuju & 18 & $36 \%$ \\
\cline { 2 - 4 } & Ragu-ragu & 2 & $4 \%$ \\
\cline { 2 - 4 } & Tidak setuju & - & - \\
\cline { 2 - 4 } & $\begin{array}{l}\text { Sangat tidak } \\
\text { setuju }\end{array}$ & - & - \\
\hline \multicolumn{2}{|l|}{ Jumlah } & 50 & $100 \%$ \\
\hline
\end{tabular}

Berdasarkan tabel di atas dapat dikemukakan bahwa hampir seluruh siswa (96 \%) menyatakan setuju jika guru agama mengajarkan mengenai macam-macam ibadah yang wajib dikerjakan. Hanya sebagian kecil yang menyatakan ragu (4\%).

Tabel 9 
Guru agama mengajarkan saya untuk bersikap jujur

\begin{tabular}{|l|l|c|c|}
\hline No & $\begin{array}{l}\text { Alternatif } \\
\text { Jawaban }\end{array}$ & Frekuensi & $\begin{array}{c}\text { Prosentase } \\
\%\end{array}$ \\
\hline 6 & $\begin{array}{l}\text { Sangat } \\
\text { setuju }\end{array}$ & 28 & $56 \%$ \\
\cline { 2 - 4 } & Setuju & 21 & $42 \%$ \\
\cline { 2 - 4 } & $\begin{array}{l}\text { Ragu- } \\
\text { ragu }\end{array}$ & 1 & $2 \%$ \\
\cline { 2 - 4 } & $\begin{array}{l}\text { Tidak } \\
\text { setuju }\end{array}$ & - & - \\
\hline $\begin{array}{l}\text { Sangat } \\
\text { tidak } \\
\text { setuju }\end{array}$ & - & - \\
\hline \multicolumn{2}{|c|}{ Jumlah } & 50 & $100 \%$ \\
\hline
\end{tabular}

Berdasarkan tabel di atas dapat dikemukakan bahwa hampir seluruh siswa (98\%) menyatakan set7uju jika guru agama mengajarkan untuk bersikap jujur. Hanya sebagian kecil yang menyatakan ragu ( $2 \%)$.

Tabel 10

Guru agama melarang siswa untuk merokok

\begin{tabular}{|l|l|c|c|}
\hline No & $\begin{array}{l}\text { Alternat } \\
\text { if } \\
\text { Jawaban }\end{array}$ & $\begin{array}{c}\text { Freku } \\
\text { ensi }\end{array}$ & $\begin{array}{c}\text { Prosenta } \\
\text { se \% }\end{array}$ \\
\hline 7 & $\begin{array}{l}\text { Sangat } \\
\text { setuju }\end{array}$ & 34 & $68 \%$ \\
\cline { 2 - 4 } & Setuju & 14 & $28 \%$ \\
\hline $\begin{array}{l}\text { Ragu- } \\
\text { ragu }\end{array}$ & 1 & $2 \%$ \\
\hline $\begin{array}{l}\text { Tidak } \\
\text { setuju }\end{array}$ & 1 & $2 \%$ \\
\hline $\begin{array}{l}\text { Sangat } \\
\text { tidak } \\
\text { setuju }\end{array}$ & - & - \\
\hline \multicolumn{2}{|c|}{ Jumlah } & 50 & $100 \%$ \\
\hline
\end{tabular}

Berdasarkan tabel di atas dapat dikemukakan bahwa hampir seluruh siswa (96\%) menyatakan menyukai perintah guru agama untuk tidak merokok. Hanya sebagian kecil yang menyatakan ragu (2\%) dan yang menyatakan tidak setuju (2\%).

Tabel 11

Guru agama mengajarkan saya untuk tidak berbohong atau membicarakan kejelekan orang lain

\begin{tabular}{|l|l|c|c|}
\hline No & $\begin{array}{l}\text { Alternatif } \\
\text { Jawaban }\end{array}$ & Frekuensi & $\begin{array}{c}\text { Prosentase } \\
\%\end{array}$ \\
\hline 8 & $\begin{array}{l}\text { Sangat } \\
\text { setuju }\end{array}$ & 32 & $64 \%$ \\
\cline { 2 - 4 } & Setuju & 16 & $32 \%$ \\
\cline { 2 - 4 } & $\begin{array}{l}\text { Ragu- } \\
\text { ragu }\end{array}$ & 2 & $4 \%$ \\
\hline $\begin{array}{l}\text { Tidak } \\
\text { setuju }\end{array}$ & - & - \\
\hline $\begin{array}{l}\text { Sangat } \\
\text { tidak } \\
\text { setuju }\end{array}$ & - & - \\
\hline \multicolumn{2}{|c|}{ Jumlah } & 50 & $100 \%$ \\
\hline
\end{tabular}

Berdasarkan tabel di atas dapat dikemukakan bahwa hampir seluruh siswa (96\%) menyatakan menyukai jika guru agama mengajarkan untuk tidak berbohong atau membicarakan kejelekan orang lain. Hanya sebagian kecil yang menyatakan ragu (4\%).

Tabel 12

Guru agama melarang siswa tawuran sesama pelajar

\begin{tabular}{|l|l|c|c|}
\hline No & $\begin{array}{c}\text { Alternatif } \\
\text { Jawaban }\end{array}$ & Frekuensi & $\begin{array}{c}\text { Prosentase } \\
\%\end{array}$ \\
\hline 9 & $\begin{array}{l}\text { Sangat } \\
\text { setuju }\end{array}$ & 29 & $58 \%$ \\
\cline { 2 - 4 } & Setuju & 17 & $34 \%$ \\
\cline { 2 - 4 } & Ragu-ragu & 2 & $4 \%$ \\
\hline \multirow{2}{*}{} & Tidak setuju & 2 & $4 \%$ \\
\cline { 2 - 4 } & $\begin{array}{l}\text { Sangat tidak } \\
\text { setuju }\end{array}$ & - & - \\
\hline \multicolumn{2}{|l|}{ Jumlah } & 50 & $100 \%$ \\
\hline
\end{tabular}

Berdasarkan tabeldi atas dapat dikemukakan bahwa hampir seluruh 
siswa (92\%) menyatakan setuju jika guru agama melarangansiswa untuk tidak tawuran sesama pelajar. Sebagian kecil yang menyatakan ragu (4 \%) dan yang menyatakan tidak setuju $(4 \%)$.

Tabel 13

Guru agama menasehati saya untuk menghormati orang tua, guru, dan teman

\begin{tabular}{|c|l|c|c|}
\hline No & $\begin{array}{c}\text { Alternatif } \\
\text { Jawaban }\end{array}$ & $\begin{array}{c}\text { Frekue } \\
\text { nsi }\end{array}$ & $\begin{array}{c}\text { Prose } \\
\text { ntase } \\
\%\end{array}$ \\
\hline 10 & $\begin{array}{l}\text { Sangat } \\
\text { setuju }\end{array}$ & 45 & $90 \%$ \\
\cline { 2 - 4 } & Setuju & 5 & $10 \%$ \\
\cline { 2 - 4 } & Ragu-ragu & - & - \\
\hline $\begin{array}{l}\text { Tidak } \\
\text { setuju }\end{array}$ & - & - \\
\cline { 2 - 4 } $\begin{array}{l}\text { Sangat } \\
\text { tidak setuju }\end{array}$ & - & - \\
\hline & Jumlah & 50 & $100 \%$ \\
\hline
\end{tabular}

Berdasarkan tabel di atas dapat dikemukakan bahwa seluruh siswa $(100 \%)$ menyatakan setuju jika guru agama memberikan nasehat untuk menghormati orang tua, guru, dan teman.

Tabel 14

Guru agama membantu siswa yang mengalami kesulitan/belum mengerti dalam belajar pendidikan agama Islam (Fiqih, Aqidah Akhlak dan SKI)

\begin{tabular}{|c|c|c|c|}
\hline No & $\begin{array}{l}\text { Alternatif } \\
\text { Jawaban }\end{array}$ & $\begin{array}{c}\text { Freku } \\
\text { ensi }\end{array}$ & $\begin{array}{c}\text { Prosenta } \\
\text { se } \%\end{array}$ \\
\hline \multirow[t]{5}{*}{11} & Sangat setuju & 10 & $20 \%$ \\
\hline & Setuju & 37 & $74 \%$ \\
\hline & Ragu-ragu & 2 & $4 \%$ \\
\hline & Tidak setuju & - & - \\
\hline & $\begin{array}{l}\text { Sangat tidak } \\
\text { setuju }\end{array}$ & 1 & $2 \%$ \\
\hline \multicolumn{2}{|r|}{ Jumlah } & 50 & $100 \%$ \\
\hline
\end{tabular}

Berdasarkan tabel di atas dapat dikemukakan bahwa hampir seluruh siswa (94\%) menyatakan setuju jika guru agama membantu siswa yang mengalami kesulitan/belum mengerti dalam belajar pendidikan agama Islam. Hanya sebagian kecil yang menyatakan ragu (4 \%) dan yang menyatakan sangat tidak setuju (2 $\%)$.

Tabel 15

Guru agama mengajukan pertanyaan kepada siswa yang berkaitan dengan materi yang telah diajarkan setiap akhir pelajaran

\begin{tabular}{|c|l|c|c|}
\hline No & $\begin{array}{c}\text { Alternatif } \\
\text { Jawaban }\end{array}$ & $\begin{array}{c}\text { Frekuen } \\
\text { si }\end{array}$ & $\begin{array}{c}\text { Prosentase } \\
\%\end{array}$ \\
\hline 12 & $\begin{array}{l}\text { Sangat } \\
\text { setuju }\end{array}$ & 8 & $16 \%$ \\
\cline { 2 - 4 } & Setuju & 32 & $64 \%$ \\
\cline { 2 - 4 } & Ragu-ragu & 8 & $16 \%$ \\
\hline \multirow{2}{*}{ Tidak setuju } & 1 & $2 \%$ \\
\hline \multirow{2}{*}{$\begin{array}{l}\text { Sangat tidak } \\
\text { setuju }\end{array}$} & 1 & $2 \%$ \\
\hline \multicolumn{2}{|l|}{ Jumlah } & 50 & $100 \%$ \\
\hline
\end{tabular}

Berdasarkan tabel di atas dapat dikemukakan bahwa sebagian besar siswa (80 \%) menyatakan setuju jika guru agama mengajukan pertanyaan yang berkaitan dengan materi yang telah diajarkan setiap akhir pelajaran. Hanya sebagian kecil yang menyatakan ragu (16 \%). Hanya sedikit sekali yang menyatakan tidak setuju (2\%) dan yang menyatakan sangat tidak setuju (2\%).

Tabel 16 
Guru agama selalu memperhatikan sikap dan tingkah laku siswa dalam kehidupan sehari-hari

\begin{tabular}{|c|l|c|c|}
\hline No & $\begin{array}{c}\text { Alternatif } \\
\text { Jawaban }\end{array}$ & $\begin{array}{c}\text { Frekue } \\
\text { nsi }\end{array}$ & $\begin{array}{c}\text { Prose } \\
\text { ntase } \\
\%\end{array}$ \\
\hline 13 & $\begin{array}{l}\text { Sangat } \\
\text { setuju }\end{array}$ & 13 & $26 \%$ \\
\cline { 2 - 4 } & Setuju & 30 & $60 \%$ \\
\cline { 2 - 4 } & Ragu-ragu & 6 & $12 \%$ \\
\cline { 2 - 4 } & $\begin{array}{l}\text { Tidak } \\
\text { setuju }\end{array}$ & 1 & $2 \%$ \\
\cline { 2 - 4 } & $\begin{array}{l}\text { Sangat } \\
\text { tidak setuju }\end{array}$ & - & - \\
\hline \multicolumn{2}{|c|}{ Jumlah } & 50 & $100 \%$ \\
\hline
\end{tabular}

Berdasarkan tabel di atas dapat dikemukakan bahwa sebagian besar siswa (86\%) menyatakan menyukai apabila guru agama memperhatikan sikap dan tingkah laku siswa dalam kehidupan sehari-hari. Hanya sebagian kecil yang menyatakan ragu (12 \%). Sedikit sekali yang menyatakan tidak setuju (2\%).

Tabel 17

Guru agama selalu mengontrol siswa saat mengikuti kegiatan ekstrakurikuler yang berkaitan dengan kegiatan keagamaan

\begin{tabular}{|c|l|c|c|}
\hline No & $\begin{array}{c}\text { Alternatif } \\
\text { Jawaban }\end{array}$ & Frekuensi & $\begin{array}{c}\text { Pros } \\
\text { entas } \\
\text { e } \%\end{array}$ \\
\hline 14 & $\begin{array}{l}\text { Sangat } \\
\text { setuju }\end{array}$ & 14 & $28 \%$ \\
\cline { 2 - 4 } & Setuju & 24 & $48 \%$ \\
\cline { 2 - 4 } & $\begin{array}{l}\text { Ragu- } \\
\text { ragu }\end{array}$ & 12 & $24 \%$ \\
\hline $\begin{array}{l}\text { Tidak } \\
\text { setuju }\end{array}$ & - & - \\
\cline { 2 - 4 } & $\begin{array}{l}\text { Sangat } \\
\text { tidak } \\
\text { setuju }\end{array}$ & - & - \\
\hline \multicolumn{2}{|c|}{ Jumlah } & 50 & 100 \\
$\%$
\end{tabular}

Berdasarkan tabel di atas dapat dikemukakan bahwa sebagian besar siswa (76 \%) menyatakan menyukai apabila guru agama selalu mengontrol siswa saat mengikuti kegiatan ekstrakurikuler yang berkaitan dengan kegiatan keagamaan. Hanya sebagian kecil yang menyatakan ragu (24\%).

2. Kondisi Motivasi Beragama (Intrinsik) Siswa SMP Islam al-Azhar 5 Cirebon dalam pelaksanaan kegiatan agama/ibadah

Tabel 18

Saya mempunyai kemauan yang tinggi untuk beribadah

\begin{tabular}{|c|l|c|c|}
\hline No & $\begin{array}{l}\text { Alternatif } \\
\text { Jawaban }\end{array}$ & Frekuensi & $\begin{array}{c}\text { Prosentase } \\
\%\end{array}$ \\
\hline 15 & $\begin{array}{l}\text { Sangat } \\
\text { setuju }\end{array}$ & 33 & $66 \%$ \\
\cline { 2 - 4 } & Setuju & 14 & $28 \%$ \\
\hline & $\begin{array}{l}\text { Ragu- } \\
\text { ragu }\end{array}$ & 3 & $6 \%$ \\
\hline $\begin{array}{l}\text { Tidak } \\
\text { setuju }\end{array}$ & - & - \\
\hline $\begin{array}{l}\text { Sangat } \\
\text { tidak } \\
\text { setuju }\end{array}$ & - & - \\
\hline \multicolumn{2}{|c|}{ Jumlah } & 50 & $100 \%$ \\
\hline
\end{tabular}

Berdasarkan tabel di atas dapat dikemukakan bahwa hampir seluruh siswa $(94 \%)$ menyatakan mempunyai kemauan yang tinggi untuk beribadah. Hanya sebagian kecil yang menyatakan ragu $(6 \%)$.

Tabel 19 
Saya melaksanakan shalat wajib 5 waktu tanpa paksaan dari orang lain

\begin{tabular}{|c|l|c|c|}
\hline No & $\begin{array}{c}\text { Alternatif } \\
\text { Jawaban }\end{array}$ & Frekuensi & $\begin{array}{c}\text { Prosentase } \\
\%\end{array}$ \\
\hline 16 & $\begin{array}{l}\text { Sangat } \\
\text { setuju }\end{array}$ & 30 & $60 \%$ \\
\cline { 2 - 4 } & Setuju & 12 & $24 \%$ \\
\hline \multirow{2}{*}{ Ragu-ragu } & 7 & $14 \%$ \\
\cline { 2 - 4 } & Tidak setuju & - & - \\
\cline { 2 - 4 } $\begin{array}{l}\text { Sangat tidak } \\
\text { setuju }\end{array}$ & - & - \\
\hline \multicolumn{2}{|l|}{ Jumlah } & 50 & $100 \%$ \\
\hline
\end{tabular}

Berdasarkan tabel di atas dapat dikemukakan bahwa sebagian besar siswa (84 \%) menyatakan mereka melaksanakan shalat wajib 5 waktu tanpa paksaan dari orang lain. Hanya sebagian kecil yang menyatakan ragu (14\%) danhanya sedikit sekali yang menyatakan sangat tidak setuju (2 $\%)$.

\section{Tabel 20}

Saya melaksanakan ajaran agama agar mendapatkan ridha dari Allah swt

\begin{tabular}{|c|l|c|c|}
\hline No & $\begin{array}{l}\text { Alternatif } \\
\text { Jawaban }\end{array}$ & $\begin{array}{c}\text { Frekue } \\
\text { nsi }\end{array}$ & $\begin{array}{c}\text { Prosentase } \\
\%\end{array}$ \\
\hline 17 & $\begin{array}{l}\text { Sangat } \\
\text { setuju }\end{array}$ & 28 & $56 \%$ \\
\cline { 2 - 4 } & Setuju & 20 & $40 \%$ \\
\cline { 2 - 4 } & Ragu-ragu & 2 & $4 \%$ \\
\cline { 2 - 4 } & $\begin{array}{l}\text { Tidak } \\
\text { setuju }\end{array}$ & - & - \\
\cline { 2 - 4 } & $\begin{array}{l}\text { Sangat } \\
\text { tidak setuju }\end{array}$ & - & - \\
\hline \multicolumn{2}{|l}{ Jumlah } & 50 & $100 \%$ \\
\hline
\end{tabular}

Berdasarkan tabel di atas dapat dikemukakan bahwa hampir seluruh siswa (96 \%) menyatakan mereka melaksanakan ajaran agama agar mendapatkan ridha dari Allah swt.
Hanya sedikit sekali yang menyatakan ragu $(4 \%)$.

Tabel 21

Saya selalu bertanya hal-hal yang tidak diketahui tentang agama kepada guru, orang tua atau Ustadz yang ada

\begin{tabular}{|c|l|c|c|}
\hline No & $\begin{array}{c}\text { Alternatif } \\
\text { Jawaban }\end{array}$ & $\begin{array}{c}\text { Freku } \\
\text { ensi }\end{array}$ & $\begin{array}{c}\text { Prose } \\
\text { ntase } \\
\%\end{array}$ \\
\hline \multirow{1}{*}{18} & Sangat setuju & 17 & $34 \%$ \\
\cline { 2 - 4 } & Setuju & 23 & $46 \%$ \\
\cline { 2 - 4 } & Ragu-ragu & 8 & $16 \%$ \\
\cline { 2 - 4 } & Tidak setuju & 1 & $2 \%$ \\
\cline { 2 - 4 } & $\begin{array}{l}\text { Sangat tidak } \\
\text { setuju }\end{array}$ & 1 & $2 \%$ \\
\hline \multicolumn{2}{|l|}{ Jumlah } & 50 & $100 \%$ \\
\hline
\end{tabular}

Berdasarkan tabel di atas dapat dikemukakan bahwa sebagian besar siswa $(80 \%)$ menyatakan selalu bertanya hal-hal yang tidak diketahui tentang agama kepada guru, orang tua atau Ustadz yang ada. Hanya sebagian kecil yang menyatakan ragu (16 \%), dan sedikit sekali yang menyatakan tidak setuju ( $2 \%)$ serta yang menyatakan sangat tidak setuju $(2 \%)$.

Tabel 22

Saya menyukai ceramah agama yang diberikan oleh guru agama Islam atau Ustadz di tempat pengajian

\begin{tabular}{|c|l|c|c|}
\hline No & $\begin{array}{l}\text { Alternatif } \\
\text { Jawaban }\end{array}$ & Frekuensi & $\begin{array}{c}\text { Prose } \\
\text { ntase } \\
\%\end{array}$ \\
\hline \multirow{1}{*}{19} & $\begin{array}{l}\text { Sangat } \\
\text { setuju }\end{array}$ & 18 & $36 \%$ \\
\cline { 2 - 4 } & Setuju & 23 & $46 \%$ \\
\cline { 2 - 4 } & $\begin{array}{l}\text { Ragu- } \\
\text { ragu }\end{array}$ & 9 & $18 \%$ \\
\cline { 2 - 4 } & $\begin{array}{l}\text { Tidak } \\
\text { setuju }\end{array}$ & - & - \\
\cline { 2 - 4 } & Sangat & - & - \\
\hline
\end{tabular}




\begin{tabular}{|l|l|l|}
\hline $\begin{array}{l}\text { tidak } \\
\text { setuju }\end{array}$ & & \\
\hline Jumlah & 50 & $100 \%$ \\
\hline
\end{tabular}

Berdasarkan tabel di atas dapat dikemukakan bahwa sebagian besar siswa $(82 \%)$ menyatakan menyukai ceramah agama yang diberikan oleh guru agama Islam atau Ustadz di tempat pengajian. Hanya sebagian kecil yang menyatakan ragu (18\%).

Tabel 23

Saya selalu mengikuti kegiatan tadarus yang dilaksanakan setiap pagi hari secara berjama'ah di halaman sekolah

\begin{tabular}{|c|l|c|c|}
\hline No & $\begin{array}{c}\text { Alternatif } \\
\text { Jawaban }\end{array}$ & Frekuensi & $\begin{array}{c}\text { Prose } \\
\text { ntase } \\
\%\end{array}$ \\
\hline 20 & $\begin{array}{l}\text { Sangat } \\
\text { setuju }\end{array}$ & 25 & $50 \%$ \\
\cline { 2 - 4 } & Setuju & 23 & $46 \%$ \\
\cline { 2 - 4 } & Ragu-ragu & 2 & $4 \%$ \\
\hline \multirow{2}{*}{} & Tidak setuju & - & - \\
\cline { 2 - 4 } & $\begin{array}{l}\text { Sangat tidak } \\
\text { setuju }\end{array}$ & - & - \\
\hline \multicolumn{2}{|l|}{ Jumlah } & 50 & $100 \%$ \\
\hline
\end{tabular}

Berdasarkan tabel di atas dapat dikemukakan bahwa hampir seluruh siswa (96 \%) menyatakan selalu mengikuti kegiatan tadarus yang dilaksanakan setiap pagi hari secara berjama'ah di halaman sekolah. Hanya sedikit sekali yang menyatakan ragu (4\%).

\section{Tabel 24}

Saya mengikuti kegiatan keagamaan di luar sekolah. Seperti: pengajian remaja, pengajian baca tulis al-Qur'an

\begin{tabular}{|c|c|c|c|}
\hline No & $\begin{array}{c}\text { Alternatif } \\
\text { Jawaban }\end{array}$ & Frekuensi & $\begin{array}{c}\text { Prosentase } \\
\%\end{array}$ \\
\hline 21 & Sangat & 18 & $36 \%$ \\
\hline
\end{tabular}

\begin{tabular}{|c|c|c|}
\hline setuju & & \\
\hline Setuju & 22 & $44 \%$ \\
\hline Ragu-ragu & 10 & $20 \%$ \\
\hline $\begin{array}{l}\text { Tidak } \\
\text { setuju }\end{array}$ & - & - \\
\hline $\begin{array}{l}\text { Sangat } \\
\text { tidak setuju }\end{array}$ & - & - \\
\hline Jumlah & 50 & $100 \%$ \\
\hline
\end{tabular}

Berdasarkan tabel di atas dapat dikemukakan bahwa sebagian besar siswa $(80 \%)$ menyatakan selalu mengikuti kegiatan keagamaan di luar sekolah. Seperti: pengajian remaja, pengajian baca tulis alQur'an. Hanya sebagian kecil yang menyatakan ragu $(20 \%)$.

Tabel 25

Saya mempraktekkan materi pelajaran PAI yang telah diajarkan di sekolah dalam kehidupan sehari-hari

\begin{tabular}{|c|l|c|c|}
\hline No & $\begin{array}{c}\text { Alternatif } \\
\text { Jawaban }\end{array}$ & Frekuensi & $\begin{array}{c}\text { Prosentase } \\
\%\end{array}$ \\
\hline 22 & $\begin{array}{l}\text { Sangat } \\
\text { setuju }\end{array}$ & 7 & $14 \%$ \\
\cline { 2 - 4 } & Setuju & 31 & $62 \%$ \\
\cline { 2 - 4 } & Ragu-ragu & 11 & $22 \%$ \\
\hline & Tidak setuju & 1 & $2 \%$ \\
\hline \multirow{2}{*}{$\begin{array}{l}\text { Sangat tidak } \\
\text { setuju }\end{array}$} & - & - \\
\hline \multicolumn{2}{|l|}{ Jumlah } & 50 & $100 \%$ \\
\hline
\end{tabular}

Berdasarkan tabel di atas dapat dikemukakan bahwa sebagian besar siswa (76 \%) menyatakan mereka mempraktekkan materi pelajaran PAI yang telah di ajarkan di sekolah dalam kehidupan sehari-hari. Hanya sebagian kecil yang menyatakan ragu (22 \%), dan sedikit sekali yang menyatakan tidak setuju (2\%).

Tabel 26 
Saya bertutur kata dan berperilaku yang sopan kepada semua orang, baik di sekolah maupun di luar sekolah

\begin{tabular}{|c|l|c|c|}
\hline No & \multicolumn{1}{|c|}{$\begin{array}{c}\text { Alternatif } \\
\text { Jawaban }\end{array}$} & $\begin{array}{c}\text { Frek } \\
\text { uens } \\
\text { i }\end{array}$ & $\begin{array}{c}\text { Prosentase } \\
\%\end{array}$ \\
\hline 23 & Sangat setuju & 22 & $44 \%$ \\
\cline { 2 - 4 } & Setuju & 25 & $50 \%$ \\
\cline { 2 - 4 } & Ragu-ragu & 2 & $4 \%$ \\
\cline { 2 - 4 } & Tidak setuju & - & - \\
\hline \multirow{2}{*}{$\begin{array}{l}\text { Sangat tidak } \\
\text { setuju }\end{array}$} & 1 & $2 \%$ \\
\hline \multicolumn{2}{|l|}{ Jumlah } & 50 & $100 \%$ \\
\hline
\end{tabular}

Berdasarkan tabel di atas dapat dikemukakan bahwa hampir seluruh siswa (94\%) menyatakan mereka selalu bertutur kata dan berperilaku yang sopan kepada semua orang, baik di sekolah maupun di luar sekolah, hanya sebagian kecil yang menyatakan ragu (4 \%) dan yang menyatakan sangat tidak setuju (2 $\%)$.

\section{Tabel 27}

Saya mendapatkan dorongan dari orang tua, guru dan teman-teman untuk lebih rajin beribadah

\begin{tabular}{|c|l|c|c|}
\hline No & \multicolumn{1}{|c|}{$\begin{array}{c}\text { Alternatif } \\
\text { Jawaban }\end{array}$} & $\begin{array}{c}\text { Frekue } \\
\text { nsi }\end{array}$ & $\begin{array}{c}\text { Prose } \\
\text { ntase } \\
\%\end{array}$ \\
\hline \multirow{2}{*}{24} & Sangat setuju & 23 & $46 \%$ \\
\cline { 2 - 4 } & Setuju & 25 & $50 \%$ \\
\cline { 2 - 4 } & Ragu-ragu & 2 & $4 \%$ \\
\hline \multirow{2}{*}{ Tidak setuju } & - & - \\
\hline $\begin{array}{l}\text { Sangat tidak } \\
\text { setuju }\end{array}$ & 1 & $2 \%$ \\
\hline \multicolumn{2}{|l|}{ Jumlah } & 50 & $100 \%$ \\
\hline
\end{tabular}

Berdasarka tabel di atas dapat dikemukakan bahwa hampir seluruh siswa $(96 \%)$ menyatakan mendapatkan dorongan dari orang tua, guru dan teman-teman untuk lebih rajin beribadah. Hanya sedikit sekali yang menyatakan ragu (4\%).

Tabel 28

Saya mengikuti kegiatan muhadhoroh di sekolah agar dapat perhatian dari guru dan teman-teman

\begin{tabular}{|c|l|c|c|}
\hline No & \multicolumn{1}{|c|}{$\begin{array}{c}\text { Alternatif } \\
\text { Jawaban }\end{array}$} & $\begin{array}{c}\text { Frekue } \\
\text { nsi }\end{array}$ & $\begin{array}{c}\text { Prose } \\
\text { ntase } \\
\%\end{array}$ \\
\hline 25 & Sangat setuju & 12 & $24 \%$ \\
\cline { 2 - 4 } & Setuju & 6 & $12 \%$ \\
\cline { 2 - 4 } & Ragu-ragu & 13 & $26 \%$ \\
\cline { 2 - 4 } & Tidak setuju & 16 & 32 \\
\cline { 2 - 4 } & $\begin{array}{l}\text { Sangat tidak } \\
\text { setuju }\end{array}$ & 3 & $6 \%$ \\
\hline \multicolumn{2}{|l|}{ Jumlah } & 50 & $100 \%$ \\
\hline
\end{tabular}

Berdasarkan tabel di atas dapat dikemukakan bahwa hampir setengah siswa (36 \%) menyatakan mereka selalu mengikuti kegiatan muhadhoroh di sekolah agar dapat perhatian dari guru dan teman-teman. Hanya sebagian kecil yang menyatakan ragu (26 \%), yang menyatakan tidak setuju (32\%),dan sedikit sekali yang menyatakan sangat tidak setuju (6\%).

Tabel 29

Saya ikhlas mengikuti kegiatan tadarus di sekolah agar menjadi pintar membaca al-

Qur'an

\begin{tabular}{|c|l|c|c|}
\hline No & \multicolumn{1}{|c|}{$\begin{array}{c}\text { Alternatif } \\
\text { Jawaban }\end{array}$} & $\begin{array}{c}\text { Freku } \\
\text { ensi }\end{array}$ & $\begin{array}{c}\text { Prose } \\
\text { ntase } \\
\%\end{array}$ \\
\hline \multirow{2}{*}{26} & Sangat setuju & 35 & $70 \%$ \\
\cline { 2 - 4 } & Setuju & 13 & $26 \%$ \\
\cline { 2 - 4 } & Ragu-ragu & 2 & $4 \%$ \\
\cline { 2 - 4 } & Tidak setuju & - & - \\
\cline { 2 - 4 } & Sangat tidak & - & - \\
\hline
\end{tabular}




\begin{tabular}{|c|c|c|}
\hline setuju & & \\
\hline Jumlah & 50 & $100 \%$ \\
\hline
\end{tabular}

Berdasarkan tabel di atas dapat dikemukakan bahwa hampir seluruh siswa (96 \%) menyatakan ikhlas mengikuti kegiatan tadarus di sekolah agar menjadi pintar membaca alQur'an. Hanya sedikit sekali yang menyatakan ragu (4\%).

Tabel 30

Saya giat belajar agama Islam agar mendapatkan nilai yang memuaskan

\begin{tabular}{|c|l|c|c|}
\hline No & $\begin{array}{c}\text { Alternatif } \\
\text { Jawaban }\end{array}$ & $\begin{array}{c}\text { Freku } \\
\text { ensi }\end{array}$ & $\begin{array}{c}\text { Prosentase } \\
\%\end{array}$ \\
\hline 27 & $\begin{array}{l}\text { Sangat } \\
\text { setuju }\end{array}$ & 23 & $46 \%$ \\
\cline { 2 - 4 } & Setuju & 24 & $48 \%$ \\
\cline { 2 - 4 } & Ragu-ragu & 3 & $6 \%$ \\
\cline { 2 - 4 } & Tidak setuju & - & - \\
\cline { 2 - 4 } & $\begin{array}{l}\text { Sangat tidak } \\
\text { setuju }\end{array}$ & - & - \\
\hline \multicolumn{2}{|l}{ Jumlah } & 50 & $100 \%$ \\
\hline
\end{tabular}

Berdasarkan tabel di atas dapat dikemukakan bahwa hampir seluruh siswa (94\%) menyatakan mereka giat belajar agama Islam agar mendapatkan nilai yang memuaskan. Hanya sedikit sekali yang menyatakan ragu $(6 \%)$.

Tabel 31

Saya melaksanakan shalat 5 waktu karena takut akan dosa dan ganjaran di akhirat nanti

\begin{tabular}{|c|l|c|c|}
\hline No & $\begin{array}{c}\text { Alternatif } \\
\text { Jawaban }\end{array}$ & $\begin{array}{c}\text { Freku } \\
\text { ensi }\end{array}$ & $\begin{array}{c}\text { Prosentase } \\
\%\end{array}$ \\
\hline 28 & $\begin{array}{l}\text { Sangat } \\
\text { setuju }\end{array}$ & 32 & $64 \%$ \\
\cline { 2 - 4 } & Setuju & 17 & $34 \%$ \\
\cline { 2 - 4 } & Ragu-ragu & - & - \\
\hline
\end{tabular}

\begin{tabular}{|c|c|c|}
\hline Tidak setuju & 1 & $2 \%$ \\
\hline $\begin{array}{l}\text { Sangat tidak } \\
\text { setuju }\end{array}$ & - & - \\
\hline Jumlah & 50 & $100 \%$ \\
\hline
\end{tabular}

Berdasarkan tabel di atas dapat dikemukakan bahwa hampir seluruh siswa $(98 \%)$ menyatakan mereka melaksanakan shalat 5 waktu karena takut akan dosa dan ganjaran di akhirat nanti. Hanya sedikit sekali yang menyatakan tidak setuju ( $2 \%)$.

Tabel 32

Saya mengikuti kegiatan yang berkaitan dengan agama Islam di sekolah karena takut dimarahi oleh guru jika tidak mengikutinya

\begin{tabular}{|c|l|c|c|}
\hline No & $\begin{array}{c}\text { Alternatif } \\
\text { Jawaban }\end{array}$ & Frekuensi & $\begin{array}{c}\text { Prosentase } \\
\%\end{array}$ \\
\hline \multirow{2}{*}{29} & Sangat setuju & 12 & $24 \%$ \\
\cline { 2 - 4 } & Setuju & 14 & $28 \%$ \\
\cline { 2 - 4 } & Ragu-ragu & 17 & $34 \%$ \\
\cline { 2 - 4 } & Tidak setuju & 3 & $6 \%$ \\
\cline { 2 - 4 } & $\begin{array}{l}\text { Sangat tidak } \\
\text { setuju }\end{array}$ & 4 & $8 \%$ \\
\hline \multicolumn{2}{|l|}{ Jumlah } & 50 & $100 \%$ \\
\hline
\end{tabular}

Berdasarkan tabel di atas dapat dikemukakan bahwa lebih dari setengah siswa (52\%) menyatakan mereka mengikuti kegiatan yang berkaitan dengan agama Islam di sekolah karena takut dimarahi oleh guru jika tidak mengikutinya. Hanya sebagian kecil yang menyatakan ragu (34\%), dan hanya sedikit sekali yang menyatakan tidak setuju (6\%) dan yang menyatakan sangat tidak setuju $(8 \%)$. 
Tabel 33

Saya melaksanakan shalat 5 waktu sebagai kebutuhan hidup

\begin{tabular}{|l|l|c|c|}
\hline No & \multicolumn{1}{|c|}{$\begin{array}{c}\text { Alternatif } \\
\text { Jawaban }\end{array}$} & $\begin{array}{c}\text { Freku } \\
\text { ensi }\end{array}$ & $\begin{array}{c}\text { Prosentase } \\
\%\end{array}$ \\
\hline 30 & Sangat setuju & 23 & $46 \%$ \\
\cline { 2 - 4 } & Setuju & 23 & $46 \%$ \\
\cline { 2 - 4 } & Ragu-ragu & 4 & $8 \%$ \\
\hline & Tidak setuju & - & - \\
\cline { 2 - 4 } $\begin{array}{l}\text { Sangat tidak } \\
\text { setuju }\end{array}$ & - & - \\
\hline \multicolumn{2}{|c|}{ Jumlah } & 50 & $100 \%$ \\
\hline
\end{tabular}

Berdasarkan tabel di atas dapat dikemukakan bahwa hampir seluruh siswa (92\%) menyatakan mereka melaksanakan shalat 5 waktu sebagai kebutuhan hidup. Hanya sedikit sekali yang menyatakan ragu (2\%).

\section{E. Interpretasi Data}

Data yang sudah diperoleh dari siswa dalam bentuk angket, dan diolah dalam bentuk Tabel distribusi frekuensi yang dilengkapi dengan prosentase dengan menggunakan rumus:

$\mathrm{P}=\frac{\mathrm{F}}{\mathrm{N}} \times 100 \%$

Keterangan:

$\mathrm{P}=$ Prosentase Tiap Jawaban

$\mathrm{F}=$ Frekuensi Jawaban

$\mathrm{N}=$ Jumlah Responden

Kemudian di interpretasikan dengan mencari jumlah ratarataprosentase yang terdapat dalam Tabel. Langkah ini digunakan untukmengetahui peran guru Pendidikan
Agama Islam dalam

meningkatkanmotivasi beragama siswa di SMP Islam al-Azhar 5 Cirebon.

Dalam menginterpretasikan nilai rata-rata prosentase yang diperoleh,penulis menentukan kriteria sebagai berikut:

\begin{tabular}{|c|l|l|}
\hline No & \multicolumn{1}{|c|}{ Prosentase } & \multicolumn{1}{|c|}{ Katagori } \\
\hline 1 & $80 \%-90 \%$ & Sangat baik \\
\hline 2 & $60 \%-79 \%$ & Baik \\
\hline 3 & $40 \%-59 \%$ & Cukup baik \\
\hline 4 & $<39 \%$ & Kurang baik \\
\hline
\end{tabular}

Tabel 34

Rekapitulasi Peran Guru Pendidikan Agama Islam

\begin{tabular}{|c|c|c|c|c|c|c|}
\hline \multirow{2}{*}{ No } & \multirow{2}{*}{$\begin{array}{c}\text { Item } \\
\text { Pernyataan }\end{array}$} & \multicolumn{5}{|c|}{ Alternatif Jawaban } \\
\hline & & SS & $S$ & $\mathrm{R}$ & $\mathrm{TS}$ & STS \\
\hline 1 & $\begin{array}{l}\text { Guru agama } \\
\text { memerintahka } \\
\text { n saya untuk } \\
\text { melaksanakan } \\
\text { shalat lima } \\
\text { waktu }\end{array}$ & $\begin{array}{c}42 \\
(84 \%)\end{array}$ & $\begin{array}{c}7 \\
(14 \%)\end{array}$ & $\begin{array}{c}1 \\
(2 \%)\end{array}$ & $\begin{array}{c}0 \\
(0 \%)\end{array}$ & $\begin{array}{c}0 \\
(0 \%)\end{array}$ \\
\hline 2 & $\begin{array}{l}\text { Guru agama } \\
\text { menasehati } \\
\text { saya agar } \\
\text { berpakaian } \\
\text { rapi dan sopan }\end{array}$ & $\begin{array}{c}39 \\
(78 \%)\end{array}$ & $\begin{array}{c}9 \\
(18 \%)\end{array}$ & $\begin{array}{c}2 \\
(4 \%)\end{array}$ & $\begin{array}{c}0 \\
(0 \%)\end{array}$ & $\begin{array}{c}0 \\
(0 \%)\end{array}$ \\
\hline 3 & $\begin{array}{l}\text { Guru agama } \\
\text { menyarankan } \\
\text { saya untuk } \\
\text { mengikuti } \\
\text { kegiatan } \\
\text { ekstrakurikule } \\
\text { r yang } \\
\text { berkaitan } \\
\text { dengan } \\
\text { keagamaan di } \\
\text { sekolah }\end{array}$ & $\begin{array}{c}15 \\
(30 \%)\end{array}$ & $\begin{array}{c}26 \\
(52 \%)\end{array}$ & $\begin{array}{c}8 \\
(16 \%)\end{array}$ & $\begin{array}{c}1 \\
(2 \%)\end{array}$ & $\begin{array}{c}0 \\
(0 \%)\end{array}$ \\
\hline 4 & $\begin{array}{l}\text { Guru agama } \\
\text { mengajarkan } \\
\text { saya untuk } \\
\text { mengucapkan } \\
\text { salam apabila } \\
\text { bertemu } \\
\text { dengan guru, } \\
\text { dan teman di } \\
\text { jalan }\end{array}$ & $\begin{array}{c}25 \\
(50 \%)\end{array}$ & $\begin{array}{c}21 \\
(42 \%)\end{array}$ & $\begin{array}{c}4 \\
(8 \%)\end{array}$ & $\begin{array}{c}0 \\
(0 \%)\end{array}$ & $\begin{array}{c}0 \\
(0 \%)\end{array}$ \\
\hline 5 & $\begin{array}{l}\text { Guru agama } \\
\text { mengajarkan } \\
\text { saya pelajaran } \\
\text { mengenai } \\
\text { macam- } \\
\text { macam ibadah } \\
\text { yang wajib }\end{array}$ & $\begin{array}{c}30 \\
(60 \%)\end{array}$ & $\begin{array}{c}18 \\
(36 \%)\end{array}$ & $\begin{array}{c}2 \\
(4 \%)\end{array}$ & $\begin{array}{c}0 \\
(0 \%)\end{array}$ & $\begin{array}{c}0 \\
(0 \%)\end{array}$ \\
\hline
\end{tabular}




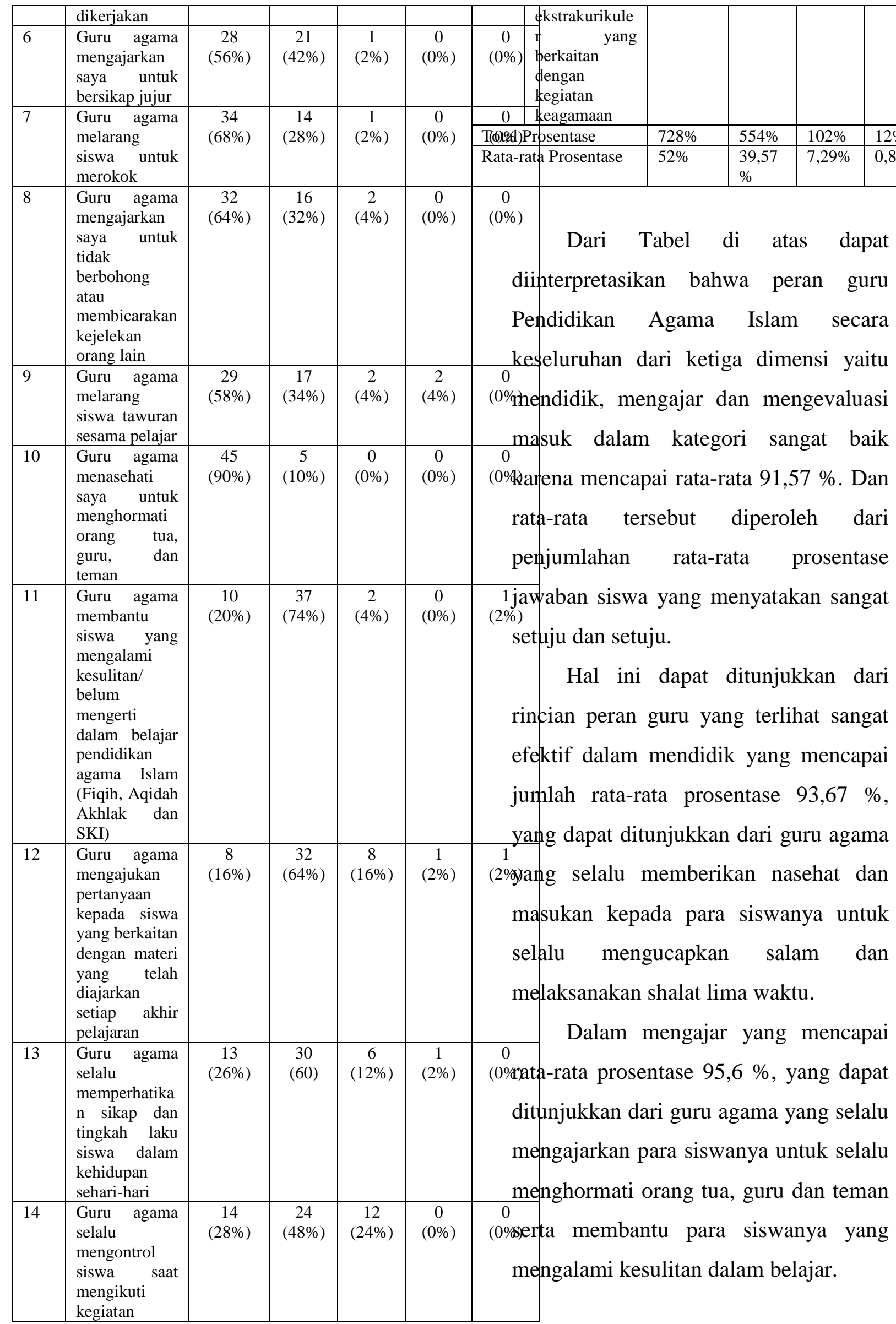


Dan dalam mengevaluasi yang mencapai jumlah rata-rata prosentase $80,66 \%$, yang dapat ditunjukkan dari intensitas guru agama yang selalu mengontrol para siswa dalam menjalankan aktivitas mereka seharihari.

Tabel 35

Rekapitulasi Motivasi Beragama Siswa

\begin{tabular}{|c|c|c|c|c|c|c|c|c|c|c|c|c|c|}
\hline \multicolumn{8}{|c|}{ 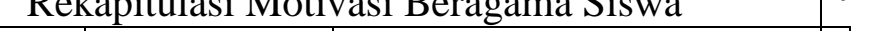 } & \multirow{4}{*}{$\begin{array}{l}\text { kata dan } \\
\text { berperilaku } \\
\text { yang } \\
\text { sopan kepada } \\
\text { semua orang, } \\
\text { baik di } \\
\text { sekolah maupun } \\
\text { di luar sekolah }\end{array}$} & \multirow{4}{*}{$\begin{array}{c}(44 \% \\
)\end{array}$} & \multirow{4}{*}{$(50 \%)$} & \multirow{4}{*}{$\begin{array}{c}(4 \% \\
)\end{array}$} & \multirow{4}{*}{$\begin{array}{l}(0 \\
\% \\
)\end{array}$} & \multirow{4}{*}{$\begin{array}{c}(2 \% \\
)\end{array}$} \\
\hline \multirow{2}{*}{ No } & \multirow[t]{2}{*}{ Item Pernyataan } & \multicolumn{5}{|c|}{ Alternatif Jawaban } & & & & & & & \\
\hline & & SS & $\mathrm{S}$ & $\mathrm{R}$ & $\begin{array}{l}\mathrm{T} \\
\mathrm{S}\end{array}$ & STS & & & & & & & \\
\hline \multirow[t]{2}{*}{1} & $\begin{array}{l}\text { Saya } \\
\text { mempunyai } \\
\text { kemauan yang } \\
\text { tinggi untuk }\end{array}$ & $\begin{array}{c}33 \\
(66 \% \\
)\end{array}$ & $\begin{array}{c}14 \\
(28 \%)\end{array}$ & $\begin{array}{c}3 \\
(6 \% \\
)\end{array}$ & $\begin{array}{c}0 \\
(0 \\
\% \\
)\end{array}$ & $\begin{array}{c}0 \\
(0 \% \\
)\end{array}$ & & & & & & & \\
\hline & beribadah & & & & & & \multirow[t]{3}{*}{0} & \multirow{3}{*}{$\begin{array}{l}\text { Saya } \\
\text { mendapatkan } \\
\text { dorongan dari } \\
\text { orang } \\
\text { tua, guru dan } \\
\text { teman-teman } \\
\text { untuk lebih } \\
\text { rajin beribadah }\end{array}$} & \multirow{3}{*}{$\begin{array}{c}23 \\
(45 \% \\
)\end{array}$} & \multirow{3}{*}{$\begin{array}{c}25 \\
(50 \%)\end{array}$} & \multirow{3}{*}{$\begin{array}{c}2 \\
(4 \% \\
)\end{array}$} & \multirow{3}{*}{$\begin{array}{l}0 \\
(0 \\
\% \\
)\end{array}$} & \multirow{3}{*}{$\begin{array}{c}0 \\
(0 \% \\
)\end{array}$} \\
\hline 2 & $\begin{array}{l}\text { Saya } \\
\text { melaksanakan } \\
\text { shalat wajib } 5 \\
\text { waktu } \\
\text { tanpa paksaan } \\
\text { dari orang lain }\end{array}$ & $\begin{array}{c}30 \\
(60 \% \\
)\end{array}$ & $\begin{array}{c}12 \\
(24 \%)\end{array}$ & $\begin{array}{l}7 \\
(14 \\
\%)\end{array}$ & $\begin{array}{l}0 \\
(0 \\
\% \\
)\end{array}$ & $\begin{array}{c}1 \\
(2 \% \\
)\end{array}$ & & & & & & & \\
\hline \multirow[t]{2}{*}{3} & Saya & 28 & 20 & 2 & 0 & 0 & & & & & & & \\
\hline & $\begin{array}{l}\text { melaksanakan } \\
\text { ajaran agama } \\
\text { agar } \\
\text { mendapatkan } \\
\text { ridha dari Allah } \\
\text { swt }\end{array}$ & $\begin{array}{c}(56 \% \\
\quad)\end{array}$ & & $\begin{array}{c}(4 \% \\
)\end{array}$ & $\begin{array}{l}(0 \\
\% \\
)\end{array}$ & $\begin{array}{c}(0 \% \\
)\end{array}$ & \multirow[t]{2}{*}{11} & \multirow{2}{*}{$\begin{array}{l}\text { Saya mengikuti } \\
\text { kegiatan } \\
\text { muhadhoroh di } \\
\text { sekolah agar } \\
\text { dapat perhatian } \\
\text { dari guru } \\
\text { dan } \\
\text { teman }\end{array}$} & \multirow[t]{2}{*}{$\begin{array}{c}12 \\
(24 \% \\
)\end{array}$} & \multirow[t]{2}{*}{$\begin{array}{c}6 \\
(12 \%)\end{array}$} & \multirow[t]{2}{*}{$\begin{array}{l}13 \\
(26 \\
\%)\end{array}$} & \multirow[t]{2}{*}{$\begin{array}{l}16 \\
(3 \\
2 \\
\% \\
)\end{array}$} & \multirow[t]{2}{*}{$\begin{array}{c}3 \\
(6 \% \\
)\end{array}$} \\
\hline \multirow[t]{2}{*}{4} & $\begin{array}{lr}\text { Saya selalu } \\
\text { bertanya }\end{array}$ & $\begin{array}{c}17 \\
(34 \%\end{array}$ & $\begin{array}{c}23 \\
(46 \%)\end{array}$ & $\begin{array}{c}9 \\
(18\end{array}$ & $\begin{array}{l}1 \\
(2\end{array}$ & $\begin{array}{c}1 \\
(2 \%\end{array}$ & & & & & & & \\
\hline & $\begin{array}{l}\text { yang tidak } \\
\text { diketahui } \\
\text { tentang agama } \\
\text { kepada guru, } \\
\text { orang tua atau } \\
\text { Ustadz yang ada }\end{array}$ & ) & & $\%)$ & $\begin{array}{c}\% \\
)\end{array}$ & ) & \multirow[t]{2}{*}{12} & $\begin{array}{l}\text { Saya ikhlas } \\
\text { mengikuti } \\
\text { kegiatan tadarus } \\
\text { di sekolah agar } \\
\text { menjadi pintar }\end{array}$ & $\begin{array}{c}35 \\
(70 \% \\
)\end{array}$ & $\begin{array}{c}13 \\
(26 \%)\end{array}$ & $\begin{array}{c}2 \\
(4 \% \\
)\end{array}$ & $\begin{array}{l}0 \\
(0 \\
\% \\
)\end{array}$ & $\begin{array}{c}0 \\
(0 \% \\
)\end{array}$ \\
\hline \multirow[t]{4}{*}{5} & \multirow{4}{*}{\begin{tabular}{lr}
\multicolumn{2}{l}{ Saya menyukai } \\
ceramah \\
yang \\
diberikan \\
guru oleh \\
Islam agama \\
Ustadz atau \\
tempat \\
pengajian \\
\end{tabular}} & \multirow{4}{*}{$\begin{array}{c}18 \\
(36 \% \\
)\end{array}$} & \multirow{4}{*}{$\begin{array}{c}23 \\
(45 \%)\end{array}$} & \multirow{4}{*}{$\begin{array}{c}9 \\
(18 \\
\%)\end{array}$} & \multirow{4}{*}{$\begin{array}{l}0 \\
(0 \\
\% \\
)\end{array}$} & 0 & & al-Qur'an & & & & & \\
\hline & & & & & & $(0 \%$ & 3 & $\begin{array}{l}\text { Saya giat belajar } \\
\text { agama Islam }\end{array}$ & $\begin{array}{c}23 \\
(45 \%\end{array}$ & $\begin{array}{c}24 \\
(48 \%)\end{array}$ & $\begin{array}{c}3 \\
6 \%\end{array}$ & $\begin{array}{c}0 \\
(0\end{array}$ & $\begin{array}{c}0 \\
(0 \%\end{array}$ \\
\hline & & & & & & & & $\begin{array}{l}\text { agar } \\
\text { mendapatkan } \\
\text { nilai yang } \\
\text { memuaskan }\end{array}$ & ) & & ) & $\%$ & ) \\
\hline & & & & & & & 4 & $\begin{array}{l}\text { Saya } \\
\text { melaksanakan }\end{array}$ & $\begin{array}{c}32 \\
(64 \%\end{array}$ & $\begin{array}{c}17 \\
(34 \%)\end{array}$ & $\begin{array}{c}0 \\
0 \%\end{array}$ & $\begin{array}{l}1 \\
(2\end{array}$ & $\begin{array}{c}0 \\
0 \%\end{array}$ \\
\hline 6 & $\begin{array}{l}\text { Saya selalu } \\
\text { mengikuti } \\
\text { kegiatan tadarus } \\
\text { yang } \\
\text { dilaksanakan }\end{array}$ & $\begin{array}{c}25 \\
(50 \% \\
)\end{array}$ & $\begin{array}{c}23 \\
(45 \%)\end{array}$ & $\begin{array}{c}2 \\
(4 \% \\
)\end{array}$ & $\begin{array}{l}0 \\
(0 \\
\% \\
)\end{array}$ & $\begin{array}{c}0 \\
(0 \% \\
)\end{array}$ & & $\begin{array}{lr} & \\
\text { karenalat } 5 \text { waktu } \\
\text { akan dosa dan } \\
\text { ganjaran di } \\
\text { akhirat nanti }\end{array}$ & )$^{(04 \%}$ & & ) & $\%$ & ) \\
\hline & $\begin{array}{l}\text { setiap pagi hari } \\
\text { secara } \\
\text { berjama'ah di } \\
\text { halaman sekolah }\end{array}$ & & & & & & 15 & $\begin{array}{l}\text { Saya mengikuti } \\
\text { kegiatan yang } \\
\text { berkaitan } \\
\text { dengan agama }\end{array}$ & $\begin{array}{c}12 \\
(24 \% \\
)\end{array}$ & $\begin{array}{c}14 \\
(28 \%)\end{array}$ & $\begin{array}{l}17 \\
(34 \\
\%)\end{array}$ & $\begin{array}{l}3 \\
(6 \\
\% \\
)\end{array}$ & $\begin{array}{c}4 \\
(8 \% \\
)\end{array}$ \\
\hline 7 & $\begin{array}{l}\text { Saya mengikuti } \\
\text { kegiatan } \\
\text { keagamaan di }\end{array}$ & $\begin{array}{c}18 \\
(36 \% \\
)\end{array}$ & $\begin{array}{c}22 \\
(44 \%)\end{array}$ & $\begin{array}{l}10 \\
(20 \\
\%)\end{array}$ & $\begin{array}{l}0 \\
(0 \\
\%\end{array}$ & $\begin{array}{c}0 \\
(0 \% \\
\end{array}$ & & $\begin{array}{l}\text { Islam di sekolah } \\
\text { karena }\end{array}$ & & & & & \\
\hline
\end{tabular}




\begin{tabular}{|c|c|c|c|c|c|c|}
\hline & $\begin{array}{l}\text { takut dimarahi } \\
\text { oleh guru jika } \\
\text { tidak } \\
\text { mengikutinya }\end{array}$ & & & & & \\
\hline 16 & $\begin{array}{l}\text { Saya } \\
\text { melaksanakan } \\
\text { shalat } 5 \text { waktu } \\
\text { sebagai } \\
\text { kebutuhan hidup }\end{array}$ & $\begin{array}{c}23 \\
(45 \% \\
)\end{array}$ & $\begin{array}{c}23 \\
(46 \%)\end{array}$ & $\begin{array}{c}4 \\
(8 \% \\
)\end{array}$ & $\begin{array}{l}0 \\
(0 \\
\% \\
)\end{array}$ & $\begin{array}{c}0 \\
(0 \% \\
)\end{array}$ \\
\hline \multicolumn{2}{|c|}{ Total Prosentase } & $716 \%$ & $630 \%$ & $\begin{array}{c}190 \\
\%\end{array}$ & $\begin{array}{l}44 \\
\%\end{array}$ & $20 \%$ \\
\hline \multicolumn{2}{|c|}{ Rata-rata Prosentase } & $\begin{array}{c}44,75 \\
\%\end{array}$ & $\begin{array}{c}39,37 \\
\%\end{array}$ & $\begin{array}{c}11,8 \\
8 \%\end{array}$ & $\begin{array}{l}2, \\
75 \\
\%\end{array}$ & $\begin{array}{c}1,25 \\
\%\end{array}$ \\
\hline
\end{tabular}

Dari tabel di atas dapat diinterpretasikan bahwa motivasi beragama siswa masuk dalam kategori sangat baik karena mencapai rata-rata $84,12 \%$. Dan rata-rata tersebut diperoleh dari penjumlahan rata-rata prosentase jawaban siswa yang menyatakan sangat setuju dan setuju. Hal ini dapat ditunjukkan dari motivasi yang dimiliki oleh para siswa sangat baik karena mereka mempunyai kesadaran dan kemauan yang sangat tinggi dalam menjalankan ibadah. keikutsertaan siswa dalam kegiatan ekstrakurikulur yang berkaitan dengan keagamaan di sekolah dan juga perilaku mereka yang sopan dan santun dalam kehidupan sehari-hari. Dan melaksanakan ibadah wajib seperti shalat lima waktu tanpa paksaaan dari orang lain.

\section{F. Kesimpulan}

Peran guru Pendidikan Agama Islam dalam mendidik, mengajar dan mengevaluasi sangat baik. Hal ini dapat dibuktikan dari hasil penelitian yang menunjukkan rata-rata peran guru Pendidikan Agama Islam tergolong sangat baik karena mencapai rata-rata $91,57 \%$.

Motivasi beragama siswa dalam pelaksanaan kegiatan agama Islam/ibadah sangat baik. Hal ini dapat dibuktikan dari hasil penelitian yang menunjukkan rata-rata motivasi beragama siswa dalam pelaksanaan kegiatan agama Islam/ibadah tergolong sangat baik karena mencapai ratarata $84,12 \%$.

\section{Daftar Pustaka}

Arifin, H. M., 1994, Ilmu Pendidikan Islam, Jakarta: Bumi Aksara

Brophy, Jere, 1986, "Teacher Influences on Student Achievement", dalam American Psychologist, vol. 41, Number 10, Oktober 1986, 69-77

Daradjat, Zakiah, et al, 2008, Metodik Khusus Pengajaran Agama Islam, Jakarta, Bumi Aksara

Djamarah, Syaiful Bahri, 2000, Guru dan anak didik dalam interaksi edukatif, Jakarta: Rineka Cipta

Majelis Permusyawaratan Rakyat RI, 1999, Garis-Garis Besar Haluan Negara, Jakarta: PT. Pabelan Jaya.

Mehdipour1,Yousef, D. Balaramulu, 2013, "The Influence of Teacher's Behavior on the Student's SelfRegulation", dalam IOSR Journal of Research \& Method in Education, Volume 1, Issue 6, May-Jun, 2013, 65-71 
Mulyasa, E., 2006, Menjadi Guru Profesional, Bandung: PT. Remaja Rosda Karya

Muhammad, Justang, 2017, Divonis 7 Tahun, Oknum Guru Narkoba di Bone Dipecat, (online) Tersedia: http://makassar.tribunnews.com/2017 /03/08/divonis-7-tahun-oknum-gurunarkoba-di-bone-dipecat

Muhaimin, 2010, Pengembangan Kurikulum Pendidikan Agama Islam di Sekolah, Madrasah Dan Perguruan Tinggi, Jakarta: PT RajaGrafindo Persada

Nurdin, H. Syafruddin, dan M. Basyiruddin Usman, 2002, Guru Profesional \& Implementasi Kurikulum, Jakarta: Ciputat Pers

Rakyat Cirebon, 2016, Bejat, Oknum Guru Agama Gagahi Siswanya, (online) Tersedia http://www.rakyatcirebon.co.id/2016/ 03/bejat-oknum-guru-agama-gagahisiswanya.html (diakses 25 April 2017)

Ramayulis, 2001, Metodologi Pengajaran Agama Islam, Jakarta: Kalam Mulia

Sanjaya, Wina, 2008, Kurikulum dan Pembelajaran, Jakarta: Kencana Prenada Media Group.

Sardiman A.M, 2000, Interaksi \& Motivasi Belajar Mengajar, Jakarta: Rajawali Press.

Usman, Moh. Uzer, 2009, Menjadi Guru Profesional, Bandung: PT. Remaja Rosda Karya.

Yasin, A. Fatah, 2008, Dimensi-dimensi Pendidikan Islam, Malang: UIN Malang Press. 